Volume III, No.1 Juni 2013/1434 H

\title{
BUNGA BANK DALAM PERSPEKTIF ISLAM (STUDI PENDAPAT NAHDLATUL ULAMA DAN MUHAMMADIYAH)
}

\author{
Abdul Salam \\ (Dosen Ekonomi Syari'ah STIA Alma Ata Yogyakarta)
}

\begin{abstract}
One of the problems is crowded and is still being debated in the Islamic economy is a matter of usury which is forbidden in the Koran . This debate mainly focused on what is really meant by riba in the Qur'an and how the economy of the Muslims who are held in the middle of the current capitalist economy and modern banking practices that require interest in economic activity .In existential presence of banking institutions can not be separated from economic problems of Muslims as a whole. Muslims who live in the modern system of value-free economy can not escape the " dependency " with banking institutions . consciously or unconsciously banking institutions have been brought up to the Muslims to accept the reality of banking today .

It is then disturb the attention of many Muslim community organizations in Indonesia to revisit karaktreristik prohibited usury, presumably withdraw in this case the researchers raised two Islamic society organizations that have a large period of the Nahdhotul Ulama ( NU ) and Muhammadiyah. Where the existence of this organization opposing the giving fatwa against religious issues in society. The subject of this paper is to examine how the public views the two organizations on bank interest.From in-depth discussion can be concluded that : For NU that bank interest law it is forbidden either privately owned banks and state-owned banks. Furthermore, NU revealed that the interest taken by depositors in the bank is forbidden usury .

As for Muhammadiyah presumably still skeptical about the

presence or absence of ' usury illat on state-owned banks, as seen with the determination, that the law is a state -owned bank interest musytabihat . Reason said musytabihat, is because there are two tendencies are lawful or unlawful, as well as in a bank that does not distinguish between people who borrow money to borrow for consumption and produced. Then this should be avoided, except in an emergency (forced). Muhammadiyah 's decision seems consistent with the notion that interest rates may have an emergency, such as Mustafa az - Zarqani opinion, saying that the bank is a reality that can not be avoided. Therefore Muslims should bermu'amalah
\end{abstract}
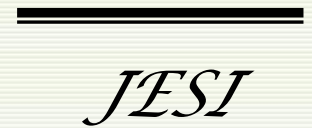

JURNAL EKONOMI SYARIAH INDONESIA 
with the bank for emergency consideration. Furthermore, Muhammadiyah states, that usury is forbidden by religion is flowering trait that is always accompanied by substance abuse and oppression chance. Being in force today did not cause a sense of oppression or disappointment by anyone interested

\section{Keywords: Bank, Interest, Riba, Nahdhotul Ulama, Muhammadiyah}

\section{A. Latar Belakang Masalah.}

Kegiatan ekonomi dari masa ke masa terus mengalami perkembangan, yang dahulu ada kini tidak ada, atau sebaliknya. Dulu institusi pemodal seperti bank tidak dikenal dan sekarang ada. Maka persoalan baru dalam fiqh muamalah muncul ketika pengertian riba dihadapkan pada persoalan bank. Di satu pihak, bunga bank (interest bank) terperangkap dalam kriteria riba, di sisi lain, bank mempunyai fungsi sosial yang besar, bahkan dapat dikatakan tanpa bank suatu negara akan hancur (Zuhri, 1996).

Dalam Ensiklopedia Indonesia, bahwa Bank (perbankan) ialah suatu lembaga keuangan yang usaha pokoknya adalah memberikan kredit dan jasa-jasanya dalam lalu lintas pembayaran serta peredaran uang, dengan mengedarkan alat tukar baru dalam bentuk uang atau giral. Jadi kegiatannya bergerak dalam bidang keuangan serta kredit dan meliputi dua fungsi yang penting yaitu sebagai perantara pemberi kredit dan menciptakan uang (Hasan, 1996).

Tidak dapat dipungkiri lagi bahwa tujuan dari suatu bank adalah mencari keuntungan dan keuntungan itu dicapai dengan berniaga kredit. Bank mendapat kredit dari orang luar dengan membayar bunga. Sebaliknya bank memberikan kredit dari kepada orang luar dengan memungut bunga yang lebih besar dari pada yang dibayarkannya. Jadi sedikit penjelasan di atas, maka yang disebut bunga bank adalah tambahan yang harus dibayarkan oleh orang yang berhutang kepada bank atau keuntungan yang diberikan pihak bank kepada orang yang menyimpan uang di bank dengan besar-kecil sesuai dengan ketentuan yang berlaku di bank tersebut. Tetapi konsensus pendapat-pendapat menganggap bahwa bunga bank merupakan tambahan tetap bagi modal, dikemukakan bahwa tambahan yang tetap ini merupakan biaya yang layak bagi proses produksi (Manan, 1997).

Jadi selisih bunga itulah keuntungan bank. Sehingga bunga merupakan suatu masalah yang tidak dapat dilepaskan dari perusahan bank dunia (umum). Mengenai kedudukan bank tersebut, Moh. Hatta mengatakan bahwa sampai saat ini berbagai ulama ada yang mengharamkan pemungutan bunga. Dengan larangan itu maka hilanglah sendi tempat bank berdiri. Kalau bunga tidak boleh dipungut, maka tidak dapat pula orang Islam untuk mendirikan bank. Lebih lanjut ia juga berpendapat, ada pula ulama yang mengatakan, bahwa memungut rente itu merupakan perbuatan yang tidak terpuji, tetapi apabila masyarakat mengkehendakinya, rente itu dibolehkan juga. Hal seperti ini menimbulkan pemahaman masyarakat tentang sifat hukum dalam Islam mempertimbangkan buruk dengan baik. Jika lebih besar baiknya dari pada

Abdul

Salam 
buruknya, hukumnya menjadi harus, pekerjaan seperti itu diperbolehkan (Fahruddin, 1985).

Sementara Mirza Nurul Huda sebagaimana dikutip oleh A. Chatib, memaparkan, bahwa satu segi kegiatan yang terpenting dari bank perdagangan adalah menerima titipan uang dari orang-orang dan meminjamkan dengan jangka pendek kepada orang lain guna menegakkan perdagangannya yang direncanakan. Oleh karena itu, maka bunga bank berdiri dan ada untuk mencari keuntungan. Apabila kita menghapus bunga sebagaimana yang diwajibkan oleh negara Islam maka bagaimana bank akan bekerja (Chotib, 1962).

Masyarakat masa awal Islam belum mengenal sistem perbankan modern dalam arti praktis, sehingga dalam menanggapi fenomena ini, terjadi pebedaan pendapat. Beda pandangan dalam menilai permasalahan ini menimbulkan kesimpulan-kesimpulan hukum yang berbeda pula, dalam hal boleh atau tidaknya, halal haramnya umat Islam bermu'amalah dengan bank. Jika kembali kepada ajaran Islam di mana al-Quran sendiri telah melarang bentuk mu'amalah yang mengandung unsur riba. Dasar persoalan riba dapat diketahui dengan jelas dan tegas dalam 3 ( tiga ) tempat :

1. Dalam al-Quran Surat al-Ruum : 39, sewaktu Nabi masih di Makkah di hadapan orang Arab Musyrikin.

2. Dalam al-Quran Surat Ali Imran : 130-132, sewaktu Nabi sudah pindah ke Madinah.

3. Dalam al-Quran Surat al-Baqarah : 275-280

Fenomena yang menarik kaitannya dengan ini adalah adanya respon dua organisasi besar Islam Indonesia dalam menyikapi masalah bunga bank tersebut, yaitu Nahdlatul Ulama melalui Bahsul Masail-nya dan Muhammadiyah dengan Majlis Tarjih-nya. Salah satu keputusan hukum tentang bunga bank yang selama ini telah beredar dalam kalangan umat Islam di antaranya adalah keputusan Mu'tamar NU XII di Malang pada tanggal 12 Rabi'ah as-Sani $1356 \mathrm{H}$ atau 25 Maret 1937 No 204, dan hasil sidang Majlis Tarjih Muhammadiyah tahun 1968 di Sidoarjo.

Telah menjadi sebuah pertanyaan besar masalah bunga bank ini dalam mu'tamar NU, terjadilah pembahasan yang begitu panjang tentang bagaimana hukum menitipkan uang dalam bank, hingga kemudian pemerintah menetapkan pajak kerena alasan mendapatkan bunga. Halalkah bunga itu? Dan bagaimana hukumnya menitipkan uang dalam bank karena menjaga keamanan saja dan tidak menginginkan bunga? Jawaban dari pertanyaan tersebut diambil dengan merujuk pada keputusan Mu'tamar NU II di Surabaya pada tanggal 12 Rabi'ah as-Sani $1346 \mathrm{H}$ atau 9 Oktober 1927 No. 28. yang memutuskan bahwa hukum Bunga bunga bank dan sehubunganya itu sama dengan hukum gadai yang telah Bank ditetapkan dalam mu'tamar tersebut.

Di antara hasil keputusan Mu'tamar NU II di Surabaya, tentang gadai telah menghasilkan tiga pendapat yaitu:

a. Haram: sebab termasuk hutang yang dipungut manfaatnya (rente).

b. Halal: sebab tidak ada syarat sewaktu akad, menurut ahli hukum yang terkenal bahwa adat yang berlaku itu tidak termasuk menjadi syarat. 
c. Syubhat (tidak tentu haram halalnya): sebab para ahli hukum masih terjadi selisih pendapat.

Sebagai catatan penting dalam keputusan mu'tamar tersebut bahwa untuk lebih berhati-hati ialah dengan mengambil pendapat pertama, yakni yang telah mengharamkannya. Adapun menitipkan uang dalam bank karena untuk keamanannya saja hukumnya makruh, dengan syarat apabila telah diyakini kalau uang tersebut akan digunakan untuk hal-hal yang bertentangan dengan ajaran agama.

Sementara keputusan Munas 'Alim Ulama NU di Bandar Lampung tanggal 21-25 Januari 1992. mengenai keputusan hukum bunga Bank ditempuh melalui prosedur yang lebih metodologis lagi, sebagai penyeimbang keputusan Muktamar NU XII di Malang. Adapun hasil keputusannya sebagai berikut :

a. Haram, kerena bunga bank dipersamakan dengan riba secara mutlak

b. Boleh, kerena bunga bank tidak dipersamakan dengan riba

c. Subhat, kerena masih belum jelas

Sementara itu, salah satu respon dari Muhammadiyah melalui keputusan Majlis Tarjih tahun 1968 di Sidoarjo Jawa Timur tentang masalah-masalah fiqh kontemporer (khususnya mengenai bunga bank) telah dilakukan dengan cara berijtihad. Dalam berijtihad Majlis Tarjih menempuh tiga metode:

1. Ijtihad Bayani, yaitu menjelaskan hukum yang kasusnya telah terdapat dalam nash al-Quran dan al-Hadis

2. Ijtihad Qiyasi, yakni menyelesaikan kasus baru dengan cara menganalogikannya dengan kasus yang hukumnya telah diatur dalam nash al-Quran dan al-Hadis

3. Ijtihad Istislahi, yakni menyelesaikan beberapa kasus baru yang tidak terdapat dalam kedua sumber di atas, dengan cara menggunakan penalaran yang didasarkan atas kemaslahatan.

Dalam menetapkan hukum bunga bank, Majlis Tarjih mangaitkannya dengan masalah riba, apakah bunga bank identik dengan riba atau tidak?, untuk memastikan jawaban tersebut, Majlis Tarjih menggunakan qiyas sebagai metode ijtihadnya. Bagi Muhammadiyah 'illat diharamkannya riba adalah adanya pengisapan atau penganiayaan (azZulm) terhadap peminjaman dana. Konsekuensinya, kalau 'illat itu ada pada bunga bank, maka bunga bank sama dengan riba dan hukumnya riba. Sebaliknya kalau 'illat itu tidak ada pada bunga bank, maka bunga bank bukan riba, kerana itu tidak haram.

Bagi Muhammadiyah 'illat diharamkannya riba disinyalir juga ada pada bunga bank, sehingga bunga bank disamakan dengan riba dan hukumnya adalah haram. Namun keputusan tersebut hanya berlaku untuk bank milik swasta. Adapun bunga bank yang diberikan oleh bank milik negara pada para nasabahnya atau sebaliknya, termasuk perkara musytabihat, tidak haram dan tidak pula halal secara mutlak (Djamil, 1995).

Dari diskripsi di atas nampak bahwa kedua organisasi tersebut mempunyai konsep yang berbeda bahkan berseberangan. Namun, keduanya mempunyai sisi kesamaan yaitu demi kemaslahatan umat

Abdul

Salam

80 
manusia, meskipun implimentasinya juga berbeda. Perbedaan tersebut terjadi karena adanya sudut pandang yang mempenagruhinya dalam menetapkan hukum tersebut.

Oleh karena itu penyusun tertarik untuk mencoba meneliti dan menelusuri kembali permasalahan-permasalahan hukum bunga bank tersebut menurut pendapat Nahdlatul Ulama melalui Bahsul Masail-nya dan Muhammadiyah dengan Majlis Tarjih-nya, dengan titik tekan pada permaslahan dasar yang melatarbelakangi dari perbedaan tersebut mengenai bunga bank adalah melalui metode pengambilan keputasan hukumnya yang diambil dari segi kajian fiqhnya,

Berdasarkan latar belakang masalah di atas, penulis tertarik untuk mengungkap bagaimana pandangan Nahdlatul Ulama (NU) dan Muhammadiyah mengenai hukum bunga bank dilihat dari segi hujjahnya?

\section{B. Telaah Pustaka}

Kemajuan ilmu pengetahuan dan teknologi dewasa ini, menuntut para ulama untuk melakukan restrukturisasi terhadap hazanah keislaman ke arah yang lebih inovatif. Termasuk di dalamnya melakukan ijtihad di bidang fiqh (hukum Islam) secara benar dan dapat dipertanggungjawabkan. Mengingat kedudukan dan fungsi ijtihad dalam yurisprudensi, maka kajian tentang fiqh yang kontemporer akan selalu menjadi aktual.

Studi tentang NU dan Muhammadiyah telah banyak dilakukan baik dari kalangan NU dan Muhammadiyah sendiri maupun dari luar serta telah dikodifikasikan. Seperti halnya Kacung Maridjan, dosen Fisip Unair, ia mengungkapkan bahwa dalam menghadapi perubahanperubahan sosial yang begitu cepat, NU tidak menutup kemungkinan akan melakukan pembaharuan (tajdid) bahkan islah pemikiran, dengan catatan bahwa pembaharuan tersebut tetap berakar pada kaidah-kaidah yang telah dianutnya. Hal ini perna dilakukan dalam Munas 'Alim Ulama di Cilacap. Meskipun buku tersebut tidak berorientasi terhadap tema pokok karya ini. Namun, Kacung Maridjan banyak memaparkan mengenai hukum bunga bank menurut NU dalam beberapa kali mu'tamar (Maridjan, 1992).

Kajian yang lain dilakukan oleh Sugiri. Dalam skripsinya, dia meneliti NU sebagai organisasi kerakyatan meminjam bahasa Dawam Raharja-dari segi penetapan hukum secara umum. Dia juga membahas istinbat hukum. Dalam NU, kalimat istinbat tidak popular, apalagi dengan diartikan ijtihad. Hal ini sulit dilakukan, karena adanya keterbatasan yang disadari oleh jami'iyyah (Sugiri, 1998).

Salah satu buku yang dikeluarkan PBNU, Ahkam al-Fuqaha' fi alMuqarrarat Mu'tamarat Nahdatu al-Ulama. Merupakan buku yang

Bunga memuat banyak tentang hasil-hasil keputusan mu'tamar yang dilakukan Bank oleh Nahdlatul Ulama dalam merespon berbagai masalah-masalah kontemporer mengenai hukum Islam. Di antaranya adalah tentang bunga bank (Hamid, t.t)

Sementara A. Wahid Zaini, pengarang buku dan kolomnis 81 produktif, dalam bukunya Dunia Pemikiran Kaum Santri secara gamblang dan detail menjelaskan hukum tentang bunga bank yang telah diputuskan oleh Munas 'Alim Ulama di Bandar Lampung, dan Majlis Tarjih 
Muhamdiyah di Sidorajo. Dengan harapan agar forum kajian atau musyawarah yang diikuti oleh ulama dan ahli-ahli perbankan agar kajiannya lebih komprehensip dan hasilnya diharapkan lebih mendekati bahkan sesuai dengan realita yang ada (Zaini, 1994).

Begitu juga dengan Majlis Tarjih Muhammadiyah yang bertugas merespon dan memutuskan persoalan-persoalan hukum Islam termasuk masalah-masalah kontemporer dengan metode ijtihadnya., di antaranya adalah masalah yang telah menjadi tema pokok pembahasan penyusun yaitu mengenai bunga bank. Di mana hasil keputusan-keputusan Majlis Tarjih tersebut selanjutnya hasil keputusan-keputusannya dibukukan dalam Himpunan Putusan Tarjih (PPM, t.t), di samping ada arsip-arsip tersendiri dari setiap Mu'tamar Tarjih.

Selanjutnya kajian yang lebih lengkap membahas tentang metode ijtihad Majlis Tarjih adalah buku karya Fathur Rahman Djamil (1995), buku ini secara detail telah menyoroti ijtihad yang dilakukan oleh Majlis Tarjih Muhammadiyah (khususnya tentang bunga bank) dengan berusaha untuk mengungkapkan kegiatan-kegiatan Majlis Tarjih Muhammadiyah yang merupakan motor penggerak tajdid Muhammadiyah.

Adapun penelitian ini tentunya berbeda dengan beberapa penelitian dan buku yang tersebut di atas. Dalam penelitian ini, lebih difokuskan terhadap penulusuran kajian tentang hasil dan keputusan mu'tamar Nahdlatul Ulama (NU) dan Muhammadiyah tentang bunga bank, dalam kapasitas keduanya sebagai representasi pemberlakuan hukum Islam dan merupakan organsisi Islam terbesar di Indonesia

\section{Kerangka Teoritik.}

Dewasa ini perbincangan mengenai riba di kalangan negeri dan para pemikir Islam mulai mencuat kembali. Sehingga upaya-upaya melakukan usaha yang bertujuan menghindari persoalan riba mulai dilakukan. Istilah dan persepsi mengenai riba begitu hidupnya di dunia Islam. Orang sering lupa bahwa hukum larangan riba, sebagaimana dikatakan oleh seorang Muslim Amerika, Cyril Glasse, bahwa riba tidak diberlakukan di negeri Islam modern manapun. Sementara itu kebanyakan orang tidak mengetahui bahwa di dunia Kristenpun, selama satu milenium, riba adalah barang yang terlarang dalam pandangan para teolog, cendekiawan maupun menurut undang-undang yang ada (Muhammad, 2000).

Di sisi lain, apabila dihadapkan pada suatu kenyataan bahwa praktek riba yang merambah ke berbagai negara ini sulit diberantas, sehingga berbagai penguasa terpaksa melakukan pengaturan dan pembatasan terhadap bisnis pembungaan uang. Perdebatan panjang di kalangan ahli fiqh tentang riba belum menemukan titik temu. Sebab mereka masing-masing memiliki alasan yang kuat. Akhirnya timbul pendapat yang bermacam-macam mengenai bunga bank dan riba.

Apakah sama persoalan "Riba" dengan "Bunga" itu? Pada lahirnya memang sama saja rupanya, kedua-duanya adalah bunga dari pada harta yang dipinjamkan. Akan tetapi pada sifatnya dalam kemajuan masyarakat sampai sekarang ada perbedaan yang cukup besar (Chatib, 1992). Pro dan

Abdul

Salam 
kontra sekitar hukum bunga bank bukan saja terjadi di kalangan sarjana muslim.

Dalam tafsir al-Manar, Abduh (dalam Nasution, 1996) dan di dalam fatwa-fatwanya, sebagaimana dicatat 'Ammarah, menyebutkan bahwa Muhammad Abduh membolehkan menyimpan uang di bank dan juga boleh mengambil bunga simpanannya, dengan kata lain ia mehalalkan bunga bank. Hal ini menurutnya, didasarkan pada maslahah-mursalah (kesejahteraan). Larangan riba menurut Muhammad Abduh adalah untuk menghindari adanya unsur eksploitasi dan menghindari memakan harta orang lain secara batil (al-Baqarah : 188).

Sementara bunga bank, menurut Abduh tidak menimbulkan adanya pemerasan dan tidak ada persamaannya dengan apa yang diharamkan al-Qur'an (al-Baqarah :188). Alasan lain yang menghalalkan menabung uang dan sekaligus mengambil bunga bank, menurut Abduh ada tiga alasan yaitu Pertama, karena dengan keberadaan perbankan yang ada sekarang tidak menciptakan penindasan, malahan sebaliknya mendorong kemajuan perekonomian. Kedua, bahwa menyimpan uang di bank, pada intinya sama artinya dengan perkongsian dalam bentuk lain. Ketiga, mendorong orang untuk maju di segala bidang, termasuk ekonomi, adalah sikap yang sangat dianjurkan dalam Islam. Sedangkan operasi dan jasa bank yang ada sekarang tampaknya memang mendorong kemajuan ekonomi (Khoirudin, 1996).

Salah satu ulama Indonesia, yang menghalalkan bunga bank, menurut catatan Khoiruddin Nasution (1996) selanjutnya adalah H. Abdullah Ahmad, seorang ulama yang berasal dari Padang, Sumatera Barat. Dia mengatakan, bunga bank boleh diambil dengan syarat, persentase bunga tersebut diumumkan lebih dahulu, sehingga jika bunga diumumkan sebelumnya maka berarti seorang yang meminjam rela dengan bunga yang diumumkan. Di sini sebagai tambahan, hendaknya agar prosentase bunga hendaknya selalu dikontrol oleh pemerintah agar bank dalam menetapkan bunga tidak sembarangan, namun mengikuti UU pemerintah

Sementara A. Hasan (1983), pemimpin Perguruan Persis Bangil, Jawa Timur, mengatakan bahwa riba yang haram, menurutnya, mempunyai sifat :

1. Terpaksa, yaitu orang terpaksa menunda hutang karena tidak mampu membayar dan pihak si peminjam menerima dengan syarat ada bayaran tambahan.

2. Darar, yaitu pinjaman yang sekiranya digunakan untuk berdagang dengan uang tersebut tidak akan bisa untuk yang cukup buat makan, minum dan bayar hutang.

Bunga

Bank
3. Berlipat ganda.

Adapun yang dihalalkan sifat-sifatnya adalah:

1. Tidak ganda-berganda.

2. Tidak membawa kepada ganda berganda.

3. Tidak mahal, artinya sekiranya orang berusaha dengan uang tersebut tidak akan membawa kepada kerugian.

4. Pinjaman yang produktif. 
Sedangkan pada tokoh yang kontra terhadap bunga bank, di antaranya adalah Mahmud Abu Su'ud, penasihat bank Pakistan, mengungkapkan bahwa bunga itu ditinjau dari segi moril dan materiil adalah memberi kemelaratan, segi morilnya ialah pengakuan dari para ahli ekonomi bahwa bunga itu memberi kemelaratan yang besar kepada rakyat dan segi materiilnya ialah bahwa kebanyakan orang yang meminjam uang itu orang-orang kaya, dan mengambil bunga dari orang-orang miskin yang meminjam uang itu tidak selayaknya.

Tokoh yang berpendapat bahwa bunga itu haram karena sangat berpegang teguh pada konteks al-Qur'an (dalam arti konteksnya bukan maknanya) yang mana al-Qur'an dan as-Sunnah dua sumber pokok Islam melarang keras adanya bunga karena kezalimannya (QS. al-Muzammil dan QS. al-Baqarah) dan mengatakan bahwa beberapa orang Islam terpelajar yang silau oleh pesona lahiriyah peradaban Eropa mengatakan bahwa yang dilarang Islam adalah riba bukan bunga. Oleh karenanya Daoualibi, seorang ahli politik dan jurnalis Syiria mengatakan, Islam semestinya membedahkan antara bunga yang dihubungkan dengan tujuan produktif dan konsumtif. Bagi pinjaman yang berhubungan dengan usaha dan tujuan produktif, seperti untuk tujuan dangang atau usaha yang lainya, maka menjadi pantas untuk mendapatkan bagian dari keuntungan yang diperoleh si peminjam. Sebaliknya, untuk pinjaman yang sifatnya untuk memenuhi kebutuhan hidup sehari-hari peminjam, maka tidak dipungut bunga dan digunakan prinsip saling tolong menolong (Nasution, 1996).

Kemudian menurut M. Abdul Manan (1997), menyatakan bahwa riba dengan nama bunga bank tidak akan mengubah sifatnya, karena bunga adalah suatu tambahan modal yang dipinjam, karena itu ia adalah riba baik dalam jiwa maupun peraturan hukum Islam. Dan ia menambahkan sebetulnya, tidak ada perbedaan yang cukup mendasar antara bunga dan riba. Islam dengan tegas melarang semua bentuk bunga betapapun hebat, dan meyakinkannya nama yang diberikan kepadanya. Tetapi dalam ekonomi kapitalis bunga adalah pusat berputarnya sistem perbankan. Dikemukan juga bahwa tanpa bunga, sistem perbankan menjadi tidak bernyawa, dan seluruh kegiatan perekonomian akan lumpuh. Sedangkan Islam adalah kekuatan dinamis dan progresif, dan jelas dibuktikan bahwa konsep Islam tentang suatu sistem perbankan bebas bunga lebih unggul dari pada perbankan modern. Pada taraf ini dapat ditetapkan bahwa suku bunga sama sekali tidak ada hubungan dengan pengaruh volume menabung.

K.H. Mas Mansur, pernah menjabat sebagai Ketua Umum PP Muhammadiyah, berpendapat, bahwa bunga bank, mendirikan bank, mengurus, mengerjakan dan berhubungan dengan bank adalah haram. Sementara, M. Bustami Ibrahim (dalam Chotib, 1962) adalah ulama Indonesia lain, yang mengharamkan bunga bank. Dalam upaya menolak bunga bank, ia berkata:

"Kita tidak usah berkilah ke sini dan kemari untuk mencari-cari jalan. Sebab Allah Maha Tahu apa yang tersembunyi dibalik itu, yang sama sekali di luar kemampuan manusia. Kita sudah melihat dengan mata kepala sendiri tentang apa manfaat dan kemudaratan bank. Maka walau bagaimana pun keadaan memaksanya, yang haram tetap haram. Sejalan

Abdul

Salam 
dengan itu, dalam hal bank, sedikit dan banyak, dengan langsung atau perantara hukumnya adalah tetap haram."

Perlu dicatat, bahwa larangan adanya bunga tidak lebih dari pada sebuah usaha proteksi terhadap orang lemah dan melawan eksploitasi yang sekaligus mendorong penanaman modal dan buruh untuk bekerja sama dengan sebutan Mudarabah.

\section{Pembahasan}

a. Sejarah Singkat Bunga Bank Konvensional.

Bangsa-bangsa dahulu telah mengenal bank, tetapi bank ini berlainan dengan bank modern, sesuai dengan awal tingkat kejadiaannya transaksi di waktu itu. Saat itu belum ada mata uang dan baru muncul pada abad pertengahan, maka timbullah lembaga perbankan yang mereka gunakan sebagai alat mata uang, pertukaran uang dengan yang lain dan penyimpanan. Hal ini sesuai dengan tingkat kemajuan yang mereka capai pada saat itu. Mereka belum mengoperasikan uang yang didepositokan pada para bankir. Kemudian para bankir berpendapat bahwa adalah lebih baik kalau uang tersebut sebagian mereka kelola, karena pada umumnya pemilik uang tidak menginkan uang yang mereka titipkan itu dioperasikan. Sehingga, dengan uang yang dititipkan itu mereka dapat mengoperasikannya dalam jumlah tertentu, seraya mereka pun dapat mengembalikan uang titipan ini pada saat penitipnya memintanya kembali. Dengan cara semacam ini, penitip (deposan) tidak mengetahui bahwa uangnya telah dioperasikan atau dikembangkan oleh si bankir, karena yang bersangutan dapat mengembalikan kepada pemiliknya kapan saja uang itu ditariknya kembali, karena uang yang dititipkan pada si bankir itu banyak, sehingga ia dapat memperbesar operasinya dan mendatangkan keuntungan yang besar pula (Hadi, 1993).

Dengan demikian si bankir berpendapat bahwa suatu hal yang menguntungkan bagi dirinya kalau penitip uang (deposan) diberi bagian dari keuntungan uang yang mereka titipkan kepadanya, sehingga uang mereka pun berkembang pula, dengan cara ini, si penitip memperoleh keuntungan dan si bankir juga mendapatkan untung yang jauh lebih besar. Bilamana si deposan tidak diberi keuntungan, barangkali mereka tidak akan menitipkan uangnya lagi pada si bankir atau tidak mengizinkan untuk dikembangkan. Karena itu, akhirnya orang-orang lain dapat digalakkan untuk menitipkan uang mereka padanya, sehingga akan bertambah investasi dan keuntungannya. Dari sinilah kemudian lahir gagasan lembaga perbankan modern (bank konvensional). Menurut Hadi (1993) yang menjadi sandaran paling besar bagi kelangsungan hidup perbankan adalah deposito, sekalipun bersandar juga pada dua sumber

Bunga

Bank lain, yaitu:

1. Modal, meliputi modal yang diberikan pemegang saham dan modal yang didapat dari keuntungan.

2. Kredit, hal ini dilakukan oleh bank-bank dagang bila membutuhkan modal, dan dipinjam dari bank sentral atau bank lain.

Menurut catatan sejarah, usaha perbankan sudah dikenal kurang lebih 2500 tahun sebelum masehi dalam masyarakat Mesir Purba dan Yunani Kuno, kemudian masyarakat Romawi (Hadiwigena, 1984). Karena 
itu, sepantasnya kalau Plato (427-347 SM) sudah berbicara tentang bahaya rente. Perkembangan bank modern mulai berkemabang di Italia dalam abad pertengahan yang dikuasai oleh beberapa keluarga untuk pembiayaan kepausan dan perdagangan wol, kemudian perbankan berkembang pesat sesudah memasuki abad ke-18 dan 19.

Bank diambil dari kata banco, bahasa Italia, artinya meja (Zuhri, 1996). Dulu para penukar uang (money changer) melakukan pekerjaan mereka di pelabuhan-pelabuhan tempat para kelasi kapal datang dan pergi, para pengembara, dan wiraswastawan turun-naik kapal. Money changer itu meletakkan uang di atas sebuah meja (banco) di hadapan mereka. Aktivitas di atas banco inilah yang menyebabkan para ahli ekonomi menelusuri sejarah perbankan, mengaitkan kata banco dengan lembaga keuangan yang bergerak dalam bidang ini dengan nama "bank". Dengan demikian, bank di sini berfungsi sebagai penukaran uang antar bangsa yang berbeda-beda mata uangnya (Zuhri, 1996).

Secara kultural, tiap peradaban manusia sebenarnya menolak keberadaan bunga bank. Apalagi dengan legitimasi ajaran agama, penolakan pun semakin kuat. Akan tetapi, kepentingan pragmatis ekonomi kapitalis meluluhlantakkannya. Para ulama fiqh mulai membicarakan tentang bunga bank (riba), ketika mereka memecahkan berbagai macam persoalan muamalah. Banyak ayat-ayat al-Qur'an yang membicarakan riba sesuai dengan periode larangan. Sampai akhirnya datang larangan yang tegas pada akhir periode penetapan hukum riba. Riba pada agama-agama langit (samawi) telah dinyatakan haram, sebagaimana yang tertuang dalam Perjanjian Lama Kitab Keluaran ayat 25 pasal 22: "Bila kamu menghutangi seseorang di antara warga bangsamu uang maka janganlah kamu berlaku laksana seorang pemberi hutang, jangan kamu meminta keuntungan padanya untuk pemilik uang." Namun orang Yahudi beranggapan bahwa riba itu hanyalah terlarang kalau dilakukan di kalangan sesama Yahudi. Tetapi tidak terlarang dilakukan terhadap non-Yahudi. Hal ini sebagaimana terdapat dalam Kitab Ulangan ayat 20 pasal 23 (Muhammad, 2000).

Kapan sebenarnya manusia mulai mempraktekkan riba? Tak ada catatan pasti tentang ini. Yang jelas, pada masa Nabi Musa AS. orangorang Yahudi dilarang mempraktekkan bunga. Larangan ini, terdapat di Old Testament (Perjanjian Lama) dan UU Talmud. Di antaranya, Kitab Deuteronomy (Ulangan) pasal 23 ayat 19: "Janganlah engkau membungakan kepada saudaramu, baik uang maupun bahan makanan atau apa pun yang dapat dibungakan"(www.sabili.or.id).

Pada masa Yunani (abad VI SM-I M), terdapat beberapa jenis bunga yang besarnya dikategorikan menurut kegunaannya. Untuk pinjaman biasa antara 6-18\%, pinjaman properti $6-12 \%$, pinjaman antar kota $7-12 \%$, sedang pinjaman perdagangan dan industri $12-18 \%$. Tapi, praktek ini dicela dua ahli filsafat, Plato dan Aristoteles. Plato beralasan, penerapan bunga menyebabkan perpecahan dan perasaan tidak puas dalam masyarakat. Selain itu, lanjut Plato, bunga merupakan alat kelompok kaya untuk mengeksploitasi masyarakat miskin. Sedangkan Aristoteles menyatakan, uang adalah alat tukar, bukan alat untuk

Abdul

Salam

86 
menghasilkan tambahan melalui bunga. Sehingga, pengambilan bunga secara tetap merupakan ketidakadilan.

Ibnu Abi Zayd (w 136 H754 M) mengungkapkan bahwa praktek riba juga melanda bangsa Arab pra-Islam, di mana riba dilakukan dengan berlipat ganda baik terhadap uang maupun berbagai macam komoditi, serta perbedaan umur berlaku bagi binatang ternak. Apabila sudah mencapai jatuh tempo, pihak piutang (kreditur) akan menanyakan kepada pihak yang berutang (debitur), apakah engkau akan melunasi sekarang atau menambah pembayaran jumlah utang yang engkau pinjam? Jika pihak debitur mempunyai sesuatu maka ia akan membayarkannya, tetapi jika hutangnya berupa binatang ternak, maka umurnya dapat meningkat (pada waktu pembayarannya). Apabila hutangnya berupa uang atau jenis komoditi lain, maka ia dapat meningkatkan dengan berlipat ganda pada waktu pengambilannya dalam jangka setiap tahun. Bila debitur tidak dapat membayarnya, maka hutang tersebut dapat berlipat lagi, misalnya hutang 100 dalam satu tahun dapat meningkat menjadi 200, jika tidak dibayar pada tahun berikutnya, hutang akan akan meningkat lagi secara berlipat ganda menjadi 400. jelasnya, keterlambatan hutang akan bertambah berlipat ganda pada setiap tahunnya (Saeed, 2003).

Sementara, di belahan dunia yang lain, pada rentang waktu yang hampir bersamaan, di saat gereja masih mengharamkan riba (abad I-XII $\mathrm{M})$, ternyata telah berkembang dengan pesat praktek perekonomian tanpa riba. Praktek ini, dimulai setahap demi setahap seiring keberhasilan dakwah Rasulullah SAW hingga terbentuknya negara Islam pertama di Madinah (sekitar tahun $3 \mathrm{H}$ ). Pelarangan total terhadap riba ini pun tercantum dengan tegas dalam QS. ar-Rum: 39, an-Nisa: 160-161, Ali Imran: 130, al-Baqarah: 278-279 dan Hadis-hadis Nabi sendiri.

Sepeninggal Rasulullah SAW. Seiring meluasnya pengaruh dan kekuasaan Islam hingga 2/3 dunia, perekonomian dan perdagangan di negeri-negeri Islam pun kian pesat berkembang. Di masa itu bermunculan ekonom-ekonom muslim yang tetap konsisten memandang riba itu haram dan keji. Misalnya, Abu Yusuf (182 H/798 M) dengan kitabnya al-Kharraj yang membahas keuangan publik dan akuntansi syariah. Kemudian, alGazali (451-505 H/1055-1110 M) dengan kitabnya Ihya' Ulumu ad-Din, Ibnu Taimiyah (661-728 H/1263-1328 M) dengan kitabnya al-Hisbah tentang konsep harga yang adil, hingga Shah Waliyullah (1114-1176 $\mathrm{H} / 1703-1762 \mathrm{M})$ dengan kitabnya al-Baliqa tentang rasionalisasi pendapatan.

Tetapi, prinsip keadilan dan kebersamaan yang dibangun oleh sistem ekonomi Islam, akhirnya harus tersingkir dari peta perkembangan ekonomi dunia yang kian kapitalistik dan pragmatis. Melunturnya praktek

Bunga Bank ekonomi tanpa riba di sebagian besar negeri muslim, berjalan berkelindan dengan menurunnya pamor dan kekuasaan negeri-negeri muslim di belahan dunia mana pun. Puncaknya terjadi pada 4 November 1922, ketika Daulah Usmaniyah Turki sebagai pemegang amanah kekhalifahan harus rela melepas kekuasaannya, setelah berkuasa selama 633 tahun di Asia, Eropa, dan Afrika.

Seiring perjalanan waktu, kekejian sistem riba secara ekonomi maupun sosial, mulai terkuak ke permukaan. Publik pun mulai melirik 
kembali sistem ekonomi tanpa riba yang pernah dicampakkannya. Akhirnya, dunia Islam pun merespon ramai-ramai keinginan umat untuk kembali hidup tanpa riba. Tak heran, di penghujung tahun 1970-an, beberapa negara Islam mulai mengembangkan industri keuangan tanpa riba. Apalagi setelah berdiri Bank Pembangunan Islam atau Islamic Development Bank (IDB), sebagai hasil dari Sidang OKI di Karachi, Pakistan, Desember 1970.

Pada akhirnya, ulama pun terlibat aktif untuk mendukung kembalinya sistem tanpa riba ini. Tak heran, jika kemudian ulama-ulama sedunia mengeluarkan fatwa yang pada intinya menegaskan kembali bahwa bunga (riba) apa pun bentuknya tetap haram, sedikit atau banyak. Di antara fatwa itu adalah: Pertama, fatwa dari Pertemuan OKI di Karachi tahun 1970. Kedua, Fatwa Kantor Mufti Negara Mesir tahun 1989 hingga 1900 yang memutuskan bunga bank termasuk salah satu bentuk riba yang diharamkan. Ketiga, Konferensi II Konsul Kajian Islam Dunia (KKID) di Universitas Al-Azhar, Cairo, Muharram 1385 H/Mei 1965 menetapkan, tak ada keraguan sedikit pun atas keharaman praktek membungakan uang seperti dilakukan oleh bank-bank konvensional. Keempat, Fatwa Lembaga Fiqh Rabitah Alam Islami Makkah dan Konferensi Islam Internasional di Jedah tahun 1976 (Abbas, 2003).

\section{b. Pengertian dan Landasan Hukum Bunga Bank.}

Secara leksikal, bunga sebagai terjemahan dari kata interest. Secara istilah sebagaimana diungkapkan dalam suatu kamus dinyatakan, bahwa "interest is a charge for a financial loan, usually a percentage of the amount loaned". Bunga adalah tanggungan pada pinjaman uang, yang biasanya dinyatakan dengan presentase dari uang yang dipinjamkan. Pendapat lain menyatakan "interest yaitu sejumlah uang yang dibayar atau dikalkulasi untuk penggunaan modal. Jumlah tersebut misalnya dinyatakan degan satu tingkat atau prosentase modal yang bersangkut paut dengan itu yang sekarang sering dikenal dengan suku bunga modal" (Muhammad, 2000).

Ada yang memebedakan antara riba dan rente (bunga) seperti Mohammad Hatta. Mantan Wakil Presiden RI, sebagaimana dikutip oleh Masjfuk Zuhdi, menerangkan bahwa riba adalah untuk pinjaman yang bersifat kosumtif, sedangkan rente adalah untuk pinjaman yang bersifat produktif, demikian pula istilah usury dan interest, bahwa usury ialah bunga pinjaman yang sangat tinggi, sehingga melampaui suku bunga yang diperbolehkan oleh hukum. Sedangkan interest ialah bunga pinjaman yang relatif rendah. Tetapi dalam realitas atau praktek menurut Maulana Muhammad Ali adalah sukar untuk membedahkan antara usury dan interest, sebab pada hakekatnya kedua-keduanya memberatkan bagi para peminjam (Zuhdi, 1998).

Oleh karena itu, apabila menarik pelajaran sejarah masyarakat Barat, terlihat jelas bahwa "interest" dan "usury" yang telah dikenal saat ini pada hakikatnya adalah sama. Keduanya berarti tambahan uang, umumnya dalam prosentase. Istilah usury muncul karena belum mapannya pasar keuangan pada zaman itu sehingga penguasa harus menetapkan suatu tingkat bunga yang dianggap wajar. Namun setelah mapannya lembaga dan pasar keuangan, kedua istilah itu menjadi hilang

Abdul

Salam

88 
karena hanya ada satu tingkat bunga di pasar yang sesuai dengan hukum permintaan dan penawaran (Muhammad, 2000).

Berbicara mengenai bunga bank, maka tidak bisa lepas dari yang namanya riba. Dan kata riba itu sendiri dari bahasa Arab yang secara etimologis berarti "tambahan" (az-Ziyadah)" (Nasution, 1996) atau "kelebihan"(Zuhdi, 1998), yakni tambahan pemabayaran atas uang pokok d pinjaman. Ada pendapat lain yang mengatakan bahwa riba merupakan kelebihan sepihak yang dilakukan oleh salah satu dari orang yang sedang bertransaksi.

Dalam pandangan sebagian mufassir, kata sandang (definite article alif lam), berarti menunjuk kasus tertentu (ma'rifah). Maka makna kata arriba yang dimaksud adalah praktek pengambilan untung dari debitur yang sudah biasa di kalangan orang-orang Arab pra-Islam ketika al-Qur'an belum diturunkan, dengan pemahaman ini, kesimpulan awal yang barangkali sangat penting untuk dicatat, bahwa untuk bias memahami ayat secara lebih tepat dan mengena, seorang harus mengetahui sebab yang melatarbelakangi turunnya ayat (asbab an-Nuzul), barulah kemudian dapat diketahui apa arti riba sebenarnya (Nasution, 1996).

Oleh karena itu, pengertian riba menurut terminologi (pendapat ulama) adalah bunga kredit yang harus diberikan oleh orang yang berhutang kepada orang yang berpiutang, sebagai imbalan untuk menggunakan sejumlah uang milik berpiutang dalam jangka waktu yang telah ditetapkan (As Sabuni, 1972). Misalnya si A memberi pinjaman pada si B dengan syarat si B harus mengembalikan uang pokok pinjaman serta sekian persen tambahannya.

Di dalam al-Qur'an dan as-Sunnah terdapat beberapa ayat yang membicarakan riba secara eksplisit di antaranya adalah:

1. Firman Allah SWT :

a) Surat Ali Imran (30): 130

b) Surat Al Baqarah (2): 275

c) Surat Al Baqarah (2): 278 - 279

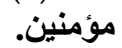

يايـهالدين

البيع

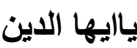

ورسوله

2. Hadis Nabi SAW:

$$
\text { وموكله وكاتبه وشاهد يه }
$$<smiles>[14CH3]</smiles>

Dari beberapa ayat dan hadis yang telah disebutkan tadi jelaslah bahwa riba itu betul-betul dilarang dalam agama Islam. Muncul sebuah pertanyaan, apakah semua riba termasuk dalam katagori arti atau maksud dari ayat dan hadits di atas?. Jawaban dari pertanyaan tersebut adalah ada

Bunga

Bank beberapa pendapat dari para ulama. Di sini dijelaskan riba nasi'ah jelasjelas dilarang karena ayat tersebut diturunkan karenanya (kejadian di masa jahiliyah). Jadi, dengan kata lain, turunnya ayat itu karena adanya riba nasi'ah. Menurut Ibnu Qayyim dalam kitab 'Ilami al-Muwaqi'in, sebagaimana dikutip Sulaiman Rasjid, mengatakan, bahwa "riba nasi'ah adalah riba yang dilakukan oleh kaum jahili di masa jahiliyah. Mereka menta-khirkan utang dari waktu yang semestinya dengan menambah 
bayaran; apabila terlambat lagi, ditambah pula terus-menerus, tiap keterlambatan wajib ditambah lagi, sampai utang yang asalnya seratus rupiah akhirnya menjadi beribu-ribu. Kalau dengan gadai, barang yang tergadai juga tetap tergadai" (Rasjid, 1997)

Pelarangan riba nasi'ah mempunyai pengertian bahwa penetapan keuntungan positif atas uang yang harus dikembalikan dari suatu pinjaman sebagai imbalan karena menanti, pada dasarnya tidak diizinkan oleh syari'ah. Tidak ada perbedan apakah uang itu dalam prosentase yang pasti dari uang pokok atau tidak, atau suatu jumlah yang harus dibayar di muka atau dikemudian hari, atau diberikan dalam bentuk hadiah atau jasa yang diterima sebagai syarat pinjaman. Inti dari permaslahan di sini adalah keuntungan positif yang ditetapkan di muka. Penting untuk dicatat bahwa menurut syari'ah, waktu tunggu selama pembayaran kembali pinjaman tidak dengan sendirinya memberikan justifikasi atas keuntungan positif dimaksud (Muhammad, 2000).

Hakikat pelarangan tersebut adalah tegas, mutlak, dan tidak mengandung perdebatan. Tidak ada ruang untuk mengatakan bahwa riba mengacu sekedar pada pinjaman dan bukan bunga, karena Nabi melarang mengambil, meskipun kecil, pemberian jasa atau kebaikan sebagai syarat pinjaman, sebagai tambahan dari uang pokok. Meskipun demikian, jika pemgembalian pinjaman pokok dapat bersifat positif atau negatif tergantung pada hasil akhir suatu bisnis, yang tidak diketahui terlebih dahulu. Ini diperbolehkan asal ditanggung bersama menurut prinsipprinsip keadilan yang ditetapkan dalam syari'ah.

\section{c. Macam-macam Riba dan Dampaknya.}

Para ahli hukum Islam (fuqaha') secara sederhana membagi riba menjadi empat macam yaitu: Pertama riba fadli, yaitu menukarkan dua barang yang sejenis dengan barang yang tidak sama. Kedua riba qardi, yaitu berutang dengan syarat ada keuntungan bagi yang memberi hutang. Ketiga riba yad, yaitu berpisah dari tempat akad sebelum timbang-terima. Keempat riba nasi'ah, yaitu disyaratkan salah satu dari kedua barang yang ditukarkan tersebut ditangguhkan penyerahannya. Riba nasi'ah juga disebut riba duyun-yakni riba yang timbul akibat utang piutang yang tidak memenuhi kriteria untung muncul bersama resiko dan hasil usaha muncul bersama biaya. Transaksi semacam ini karena mengandung pertukaran kewajiban menanggung beban hanya karena berjalannya waktu (Rasjid, 1997).

Sebagian ulama ada yang membagi riba tersebut atas tiga macam, yaitu riba fadli, riba yad, dan riba nasi'ah. Riba qardi termasuk ke dalam riba nasi'ah. Barang-barang yang berlaku riba padanya adalah emas, perak, dan makanan yang mengenyangkan atau berguna untuk yang mengenyangkan, misalnya garam. Jual beli barang tersebut, kalau sama sejenisnya seperti emas dengan emas, gandum dengan gandum diperlukan tiga syarat: 1 . Tunai; 2 . Serah terima; dan 3. Sama timbangannya. Kalau jenisnya berlainan, tetapi 'illat ribanya satu seperti emas dengan perak boleh tidak sama timbangannya, tetapi mesti tunai dan timbang terima. Kalau jenis dan 'illat ribanya berlainan perak dengan beras, boleh dijual bagaimana saja seperti barang-barang yang lain; berarti tidak diperlukan suatu syarat dari yang tiga tersebut. 
Sementara Ibnu Qayyim, membagi riba atas dua bagian: jali dan khafi. Riba jali adalah riba nasi'ah, diharamkan karena mendatangkan mandharat yang besar. Riba yang sempurna (riba al-kamil) adalah riba nasi'ah. Riba ini berjalan pada masa jahiliyah. Sedangkan riba khafi diharamkan untuk merutup terjadinya riba jali (wa al-khafi haramun li annahu zari'atun ila al-jali) (Sukarja dalam chuzaimah, 1995).

Semua agama samawi (revealed relegion) telah melarang praktek bunga bank, karena dapat menimbulkan dampak bagi masyarakat pada umumnya dan bagi mereka yang terlibat langsung pada praktek riba pada khususnya. Adapun dampak akibat dari praktek riba adalah:

1. Menyebabkan eksploitasi (pemerasan) oleh si kaya terhadap si miskin.

2. Uang modal besar yang dikuasai oleh the haves tidak disalurkan ke dalam usaha-usaha yang produktif, misalnya pertanian, perkebunan, industri, dan sebagainya yang dapat ciptakan lapangan kerja banyak, yang sangat bermanfaat bagi masyarakat dan juga bagi pemilik modal itu sendiri, tetapi modal besar itu justru disalurkan dalam perkreditan berbunga yang belum produktif.

3. Bisa menyebabkan kebangkrutan usaha dan pada gilirannya bisa mengakibatkan keretakan rumah tangga, jika si peminjam itu tidak mampu untuk mengembalikan pinjaman dan bunganya (Zuhdi, 1997) .

4. Riba dapat menimbulkan permusuhan antara pribadi dan mengurangi semangat kerja sama atau saling menolong dengan sesama manusia, dengan mengenakan tambahan kepada peminjam akan menimbulkan prasaan bahwa peminjam tidak tahu kesulitan dan tidak mau tahu penderitaan orang lain.

5. Riba merupakan salah satu bentuk penjajahan. Kreditur yang meminjamkan modal dengan menenutut pembayaran lebih kepada peminjam dengan nilai yang telah disepakati bersama menjadikan kreditur mempunyai legitimasi untuk melakukan tindakantindakan yang tidak baik untuk menuntut keasepakatan tersebut. Karena dalam kesepakatan kreditur telah memperhitungkan keuntungan yang telah diperoleh dari kelibahan bunga yang akan didapat, dan itu sebenarnya hanya berupa pengharapan dan belum terwujud.

d. Bank Konvensional (sistem bunga) dan Bank Islam.

Bank sebagai lembaga keuangan yang melalui kegiatankegiatannya menarik uang dari yang menyalurkannya kepada masyarakat, dengan usaha pokoknya memberikan kredit dan jasa-jasa dalam lalu lintas

Bunga Bank pembayaran dan peredaran uang. Bagi negara yang sedang berusaha meningkatkan ekonominya mempunyai peranan dan posisi yang sangat penting, terutama kaitannya dengan kontak-kontak ekonomi negara lain. Sulit dibayangkan melakukan kegiatan-kegiatan ekomomi tanpa behubungan dengan bank.

Dalam kehidupan modern seperti sekarang ini, umat Islam hampir tidak bisa menghindari diri dari bermuamalah dengan bank konvensional dalam segala aspek kehidupannya, termasuk kehidupan agamanya. 
Misalnya ibadah haji di Indonesia umat Islam masih harus memakai jasa bank, apalagi dalam kehidupan ekonomi tidak bisa lepas dari yang namanya jasa perbankan. Sebab tanpa jasa bank, perekonomian Indonesia tidak selancar dan semaju seperti sekarang ini (Zuhdi, 1997).

Istilah "Bank Konvensional" dalam hal ini dimaksudkan sebagai sebutan bagi bank yang dipraktekkan orang pada umumnya sebelum bank Islam lahir. Yaitu bank dengan penerapan sistem bunga. Usia lembaga perbankan sebenarnya sudah tua sehingga ketika orang Islam mulai melakukan kontak dengan bank, ia sudah berada pada tahap perbangkan dengan pola modern. Karenanya, benar bahwa kegiatan perbankan dengan sistem bunga disebut sebagai persoalan baru dalam kajian keislaman.

Dalam perekonomian modern, pada dasarnya bank adalah lembaga perantara dan penyalur dana antara pihak yang berkelebihan dana dengan pihak yang kekurangan dana. Peran ini disebut "Financial Intermediary". Dalam melaksanakan tugasnya yang paling menonjol sebagai financial intermediary itu, bank dapat dikatakan membeli uang dari masyarakat pemilik dana ketika ia menerima simpanan, dan menjual uang kepada masyarakat yang memerlukan dana ketika ia memberi pinjaman kepada mereka. Dalam kegiatan ini muncul apa yang disebut bunga. Sri Edi Swasano, seorang pakar muslim dalam disipilin ilmu ekonomi, berpendapat bahwa bunga adalah harga uang dalam transaksi jual-beli tersebut. Dengan demikian, bunga yang ditarik oleh bank dari pemakai jasa, merupakan ongkos adminitrasi dan ongkos sewa. Sehingga dari sini kelihatan bahwa penyimpanan uang di bank akan mendapat bagian keuntungan dari bank berupa bunga yang diambilkan dari bunga yang diterima oleh bank (Zuhri, 1996).

Sebagai bank yang menerapkan sistem bunga, mekanisme perbankan konvensional sebagian besar ditentukan oleh kemampuannya dalam menghimpun dana masyarakat melalui pelayanan dan bunga yang menarik (muhammad, 2000) Suatu tingkat bunga simpanan akan dikatakan menarik manakalah: Pertama, lebih tinggi dari tingkat inflasi, karena pada tingkat bunga yang lebih renda, dana yang disimpan nilainya akan dikikis inflasi. Kedua, lebih tinggi dari tingkat bunga riil di luar negeri karena pada tingkat bunga yang lebih rendah dengan dianutnya sistem devisa bebas, dana-dana besar akan lebih menguntugkan untuk disimpan (diinvestasikan) di luar negeri. Ketiga, lebih bersaing di dalam negeri, karena penyimpanan dana akan memilih bank yang paling tinggi menawarkan tingkat bunga simpanannya dan memberikan berbagai jenis bonus atau hadiah. Kemudian pada sisi penyaluran dana tingkat bunga simpanan itu ditambah dengan prosentasi tertentu untuk spread yang terdiri dari; Biaya operasional, Cadangan kredit macet, Cadangan wajib, dan Profit marjin, dibebankan kepada peminjam dana. Artinya peminjam dana-lah yang sebenarnya membayar bunga simpanan dan spread bagi bank tersebut.

Sebagai intermediary, bank lalu memperoleh spread sebagai salah satu sumber pendapat yang pada umumnya justru merupakan pendapatan utama. Hal tersebut di atas mengandung makna bahwa satu tingkat bunga simpanan yang tinggi itu bisa terjadi karena adanya tingkat inflasi yang tinggi, tingkat bunga riil di luar negeri yang tinggi, dan tingkat persaingan

Abdul

Salam 
antar bank yang tinggi. Sebaliknya suatu tingkat buga pinjaman yang tinggi bisa terjadi karena tingkat bunga simpanan yang tinggi sebagai sumber dana dan tingkat spread yang tinggi pula (Muhammad, 2000). Proses penentuan tingkat bunga seperti tersebut di atas cenderung lebih mudah mengakomodir kenaikan dari pada penurunan tingkat bunga. Karena untuk menurunkan tingkat bunga harus dimulai dari menurunkan tingkat bunga simpanan yang mengandung resiko pindahnya penyimpanan dana dari bank yang menurunkan tingkat bunga ke bank yang memberikan tingkat bunga lebih tinggi. Oleh sebab itu, siapa yang berani terlebih dahulu menurunkan tingkat bunga? Tentu saja tidak ada walaupun melalui kesepakatan antar bank yang ada. Kesepakatan semacam itu sulit dilaksanakan karena adanya perbedaan kekuatan masing-masing bank. Di lain pihak, beban bunga pinjaman yang dibayar peminjam kepada bank itu lazimnya sebanyak mungkin akan digeserkan oleh peminjam dana kepada penanggung yang terakhir.

Jadi, apabila peminjam dana adalah perorangan untuk keperluan konsumtif, maka beban bunga pinjaman tadi tentunya harus ditangani sendiri. Tetapi apabila peminjam dana adalah pedangang maka logislah apabila beban bunga pinjaman itu digeserkannya kepada harga barang yang dijual. Dari mekanisme kerja antar bank dengan nasabah inilah, baik nasabah peminjam maupun nasabah penyimpan, maka bank konvensional tidak dapat mempertahankan hidupnya, apalagi mengembangkannya tanpa mekanisme sistem bunga. Oleh karenanya, di sini dapat diambil sedikit pengertian segi positif bank dari sistem bunga yaitu dengan melalui sistem bunga, bank dapat melaksanakan aktivitas perbankannya, namun dibalik semua segi positif dari sistem bunga, ternyata masih banyak kejelekan-kejelekan dari diterapkannya bank konvensional (sistem bunga). Diantaranya adalah (Nasution, 1996): Pertama, dengan sistem ini, para wisatawan, pemerintah dan kelompok konsumen, berada dalam posisi yang terpojok. Sebab, kelompok ini akan mempunyai beban hutang dari sumber keuangan.

Kedua, kelompok yang bisa mendapatkan pinjaman pada umumnya hanyalah kelompok yang mempunyai jaminan yang lebih tinggi dan lebih terjamin. Sementara banyak kelompok lain yang lebih membutuhkan pinjaman dan mempunyai usaha yang lebih layak untuk dikembangkan, tidak mendapatkan pinjaman hanya karena tidak memiliki jaminan yang cukup dan aman. Ketiga, mengakibatkan tidak meratanya distribusi pendapatan. Sebagai contoh konkrit, dapat dilihat pekerjaan yang dilakukan perusahan, mulai dari proses produksi, pengelolahan sampai pada proses pemasaran. Dengan usaha yang sedemikian berat, pihak perusahaan masih penuh tanda tanya, antara berhasil atau tidak. Bunga Sementara pihak bank sendiri, hanya dan tinggal mengambil bunga Bank bulanan. Keempat, perbankan dengan sistem bunga tidak mengenal adanya perbedaan antara peminjam komsumtif dan produktif. Padahal terlalu banyak orang yang meminjam uang untuk kebutuhan kosumsi, baik berupa kebutuhan sehari-hari, maupun untuk bekal masa depan yang 93 sangat dibutuhkan, seperti rumah dan semacamnya. Semua kebutuhan konsumen tersebut, sama sekali tidak ada kemungkinan untuk mendapatkan keuntungan. Sementara bank mebebankan bunga yang sama 
dengan perusahaan-perusahaan yang masih ada kemungkinan untuk mendapatkan keuntungan. Kelima, pihak bank juga tidak membedakan antara kebutuhan usaha dengan kebutuhan-kebutuhan umum, seperti kebutuhan air minum, listrik dan semacamnya. Padahal hal-hal semacam itu merupakan kebutuhan masyarakat secara umum. Sementara pihak bank tidak membedakan kebutuhan tersebut dengan pinjaman untuk kepentingan lainnya. Akibatnya adalah munculnya konsentrasi kekuatan keuangan di pihak bank. Sehinga akibat selanjutnya adalah munculnya ketidakmerataan pendapatan, yang bisa terjadi akan memunculkan inflasi.

Untuk itu Islam sebagai agama rahmatan lil'alamin, berusaha melalui para pakar muslim yang berkecimpung dalam dunia ekonomi untuk memberikan solusi terhadap sistem bunga bank, yaitu dengan mendirikan bank Islam (Sukarja, 1995), di mana prinsip yang dipakai dalam bank Islam ini adalah tidak didasarkan pada sistem bunga, melainkan lewat sistem bagi hasil (Muhammad, 2000). Bank tanpa bunga ini akan menyediakan fasilitas kredit dan melaksanakan semua fungsi bank perdagangan. Prinsip bagi hasil akan mendorong investor untuk menanam uang mereka di bank non konvensional, sebab kongsi dalam bank ini akan menanggung untung dan rugi secara bersama, yang berbeda dengan sistem perbankan modern di mana kerugian hanya akan ditanggung oleh peminjam, sedangkan pemberi pinjaman dalam hal ini adalah pihak bank akan selalu mendapatkan keuntungan (Muslehuddin, 1994).

Sebagai pengganti sistem bunga, bank Islam menggunakan berbagai cara atau prinsip yang bersih dari unsur riba, antara lain adalah sebagai berikut: Pertama. Wadiah, yaitu titipan uang, barang, dan suratsurat berharga atau deposito. Lembaga figh Islam "wadiah" ini, bisa diterapkan oleh bank Islam dalam operasinya menghimpun dana dari masyarakat, dengan cara menerima deposito berupa uang, surat-surat berharga sebagai amanat yang wajib dijaga keselamatannya oleh bank Islam. Bank berhak menggunakan dana yang didepositokan itu tanpa harus membayar imbalannya (rente atau riba), tetapi bank harus menjamin bisa mengembalikan dana itu pada waktu pemiliknya (depositor) memerlukannya (Zuhdi, 1997).

Kedua. Mudarabah, yaitu suatu usaha kerjama antara tenaga kerja dengan pemilik modal bergabung bersama-sama sebagai mitra usaha untuk kerja. Ini bukan semata-mata usaha dalam arti modern. Ia punya kelebihan karena Islam telah memberikan kode etik ekonomi yang menggabungkan nilai material dan spiritual untuk jalankan sistem ekonominya. Kode etik ekonomi ini harus dicerminkan bila prinsip mudarabah dilaksanakan dalam praktek. Sistem perbankan Islam dapat membantu pembentukan lembaga tertentu atas dasar mudarabah dan dengan demikian, dapat menyelesaikan pertentangan yang berabad-abad lamanya antara tenaga kerja dan majikannya (Mannan, 1997).

Sungguh menyenangkan melihat bank Islam turut mngurus kontrak mudarabah, yaitu bank memberikan modal, sedangkan para nasabah memberikan keahlian mereka, sementara keuntungan dibagi menurut rasio yang disetujui. Telah dikemukan bahwa prinsip mudarabah Abdul Salam dapat dimintakan dalam hal transaksi jangka pendek yang dapat 
membiayai dirinya sendiri (self liquidating), dan akibatnya permintaan untuk pinjaman jangka pendek sedikit- banyak dapat dikurangi, karena dalam ekonomi Islam pinjaman jangka pendek dengan bunga seperti yang diberikan bank dagang tradisional atau lembaga diskonto tidak akan tersedia.

Ketiga. Musyarakah (persekutuan), yaitu kerja sama antara pihak bank dan pihak pengusaha yang sama-sama memiliki andil (saham) pada usaha persekutuan (join venture). Karena itu, kedua belah pihak berpartisipasi langsung mengelola usaha perseketuan tersebut mulai dari menanggung untung dan ruginya bersama atas dasar perjanjian profit and lose sharing (PLS agreement). Sehingga dengan musyarakah ini, baik bank atau klien menjadi mitra usaha dengan menyumbangkan modal dalam berbagai tingkat dan mencapai kata sepakat atas suatu rasio laba di muka untuk suatu waktu tertentu.

Keempat. Murabahah, yaitu jual beli barang dengan tambahan harga atau cost plus atas dasar harga pembelian yang pertama secara jujur. Dengan murabahah ini, orang pada hakikatnya ingin mengubah bentuk bisnisnya dari kegiatan pinjam-meminjam menjadi transaksi jual beli (lending activity menjadi sale and purchase transaction) (Zuhdi, 1997). Di sini bank Islam bisa membelikan atau menyediakan barang-barang yang diperlukan oleh pengusaha untuk dijual lagi, dan bank minta tambahan harga (cost plus) atas harga pembelinya. Syarat transaksi murabahah ini adalah si pemilik barang, dalam hal ini bank Islam harus memberikan informasi yang sebenarnya atau sejujurnya kepada pembeli tentang harga pembeliannya dan keuntungan bersihnya (profit margin) dari pada cost plus-nya itu.

Kelima. Qard Hasan, yaitu pinjaman yang baik (benevolent loan). Bank Islam dapat memberikan pinjaman tanpa bunga kepada para nasabah yang baik, terutama nasabah yang memiliki deposito di bank Islam itu sebagai salah satu service dan penghargaan bank terhadap para deposan, karena deposan tidak menerima bunga atas depositonya dari bank Islam.

Keenam. Bank Islam dalam melakukan transaksi juga diperbolehkan memungut dan menerima pembayaran untuk; 1 . Mengganti biaya-biaya yang langsung dikeluarkan oleh bank dalam melaksanakan pekerjaan untuk kepentingan nasabah, misalnya biaya telegram, telepon, telex dalam memindahkan atau memeberitahukan rekening nasabah dan sebagainya. 2. Membayar gaji para karyawan bank yang melakukan pekerjaan untuk kepentingan nasabah, dan untuk sarana dan prasarana yang disediakan oleh bank, dan biaya adminitrasi pada umumnya.

Dari keterangan tersebut di atas, dapat dikemukakan bahwa perbedaan prinsipil antara sistem bank konvensional dengan bank bebas Bunga bunga (bank Islam) adalah terletak pada cara penentuan keuntungan. Pada Bank bank konvensional misalnya, jasa atau bunga pinjaman ditentukan lebih dahulu dan diperhitungkan menurut besar bunga yang ditetapkan dan jumlah pinjaman atau tabungan (Sukarja, 1995). Seorang atau suatu badan hukum yang meminjam uang dari bank sejak mulai hari pinjaman atau 95 sejak saat yang ditentukan dalam perjanjian, ia sudah menanggung beban membayar bunga, tanpa diperhitungkan apakah uang pinjaman itu akan mendatangkan hasil atau tidak. 
Sementara bank Islam menetukan keuntungan menurut laba yang telah diperoleh. Kedua belah pihak sama-sama menanggung untung dan rugi. Keuntungan bisa naik atau turun tergantung kepada besar kecilnya laba yang diperoleh. Kepada peminjam, bank Islam tidak menentukan bunga dan kepada penabung tidak memberikan bunga, yang diberikan adalah keuntungan yang diperhitungkan atas dasar besar kecilnya laba yang didapat.

\section{e. Nahdlatul Ulama (Nu) Dan Muhammadiyah}

a) Nahdlatul Ulama dan Pandangannya tentang Bunga Bank - Pokok-pokok Pikiran.

Nahdlatul Ulama (NU) merupakan organisasi sosial keagamaan yang berhaluan Ahlu as-Sunnah Wa al-Jama'ah (Zaini, 1994), sebagai wadah pengemban dan mengamalkan ajaran Islam Ala Ahadi al-Mazhabi al-Arba'ah dalam rangka mewujudkan Islam sebagai rahmat bagi semesta alam (SekJen NU, 1999). Dengan kata lain sebagai salah satu ormas tertua, NU merupakan satu-satunya organisasi masa yang secara keseluruhan bahwa Ahlu as-Sunnah Wa al-Jama'ah sebagai mazhabnya (Shodiq, 2000). Sehingga, ketika NU berpegang pada mazhab, berarti mengambil produk hukum Islam (fiqh) dari empat Imam Mazhab, yaitu mazhab Hanafi, mazhab Maliki, mazhab Syafi'i dan mazhab Hambali (Pasha dan Darban, 2000). Dalam kenyataan NU lebih condong pada pendapat Imam asySyafi'I, oleh karenanya NU sering "dicap" sebagai penganut fanatik mazhab Syafi'i. Hal ini dapat dilihat dari cara NU mengambil sebuah rujukan dalam menyelesaikan kasus-kasus atau permasalahanpermasalahan yang muncul. Alasan yang sering dilontarkan adalah umat Islam Indonesia manyoritas bermazhab Syafi'i.

Nahdlatul Ulama (NU) sebagai Jam'iyah Diniyah Islamiyah yang bertujuan membagun atau mengembangkan insan dan masyarakat yang bertaqwa kepada Allah SWT senantiasa berpegang teguh pada kaidahkaidah keagamaan (ajaran Islam) dan kaidah-kaidah fiqh lainnya dalam merumuskan pendapat, sikap dan langkah guna memajukan jam'iyah tersebut. Dalam bidang keagamaan dan kemasyarakatan alam pikiran (pokok ajaran) Nahdlatul Ulama (NU) secara ringkas dapat dibagi menjadi tiga bidang ajaran yaitu; bidang aqidah, fiqh, dan tasawuf (Amin, 1996).

Dalam bidang aqidah yang dianut oleh NU sejak didirikan pada 1926 adalah Islam atas dasar Ahlu as-Sunnah Wa al-Jama'ah. Faham ini menjadi landasan utama bagi NU dalam menentukan segala langkah dan kebijakannya, baik sebagai organisasi keagamaan murni, maupun sebagai organisasi kemasyarakatan. Hal ini ditegaskan dalam Anggaran Dasar dan Anggaran Rumah Tangga (AD/ART)., bahwa NU mengikuti Ahlu asSunnah Wa al-Jama'ah dan menggunakan jalan pendekatan (mazhab). Adapun faham Ahlu as-Sunnah Wa al-Jama'ah yang dianut NU adalah faham yang dipelopori oleh Abu Hasan al-Asy'ari dan Imam Abu Mansur al-Maturidi (Shodik, 2000). Keduanya dikenal memiliki keahlian dan keteguhan dalam mempertahankan i'tiqad (keimanan) Ahlu as-Sunnah Wa al-Jama'ah seperti yang telah disyaratkan oleh Nabi SAW dan para sahabatnya. Jadi dalam melaksanakan ajaran Islam, bila dikaitkan dengan

Abdul

Salam

96 
masalah-masalah aqidah harus memilih salah satu di antara dua yaitu alAsy'ari dan al-Maturidi.

Sementara dalam bidang fiqh ditegaskan bahwa: Nahdlatul Ulama (NU) sebagai Jam'iyah Diniyah Islamiyah beraqidah Islam menurut faham Ahlu as-Sunnah Wa al-Jama'ah dan mengikuti faham salah satu mazhab empat: Hanafi, Maliki, Syafi'i dan Hambali. Namun dalam prakteknya para Kyai adalah penganut kuat dari pada mazhab Syafi'I (Shodik, 2000).

Jadi dengan demikian NU memegang produk hukum Islam (fiqh) dari salah satu empat mazhab tersebut-artinya bahwa dalam rangka mengamalkan ajaran Islam, NU menganut dan mengikuti bahkan mengamalkan produk hukum Islam (fiqh) dari salah satu empat mazhab empat sebagai konsekuensi dari menganut faham Ahlu as-Sunnah Wa alJama'ah. Walaupun demikian tidak berarti terus Nahdlatul Ulama tidak lagi menganut ajaran yang diterapkan Rasulullah SAW. sebab keempat mazhab tersebut dalam mempraktekkan ajaran Islam juga mengambil landasan dari al-Qur'an dan as-Sunnah di samping Ijma' dan Qiyas sebagai sumber pokok penetapan hukum Islam (Amin, 1996).

Adapun alasan kenapa Nahdlatul Ulama dalam bidang hukum Islam (fiqh) lebih berpedoman kepada salah satu dari empat mazhab; Pertama, al-Qur'an sebagai dasar hukum Islam yang pokok atau utama bersifat universal, sehingga hanya Nabi SAW. yang tahu secara mendetail maksud dan tujuan apa yang terkandung dalam al-Qur'an. Nabi SAW sendiri menunjukkan dan menjelaskan makna dan maksud dar al-Qur'an tersebut melalui sunnah-sunnah beliau-yaitu berupa perkataan, perbuatan, dan taqrir. Kedua, sunnah Nabi SAW. yang berupa perkataan, perbuatan, maupun taqrirnya yang hanya diketahui oleh para sahabat yang hidup bersamaan (semasa) dengan beliau, oleh karena itu perlu untuk memeriksa, menyelidiki dan selanjutnya berpedoman pada keterangan-leterangan para sahabat tersebut. Namun sebagian ulama tidak memperbolehkan untuk mengikuti para sahabat dengan begitu saja. Maka dari itu untuk mendapatkan kepastian dan kemantapan, maka jalan yang ditempuh adalah merujuk kepada para ulama mujtahidin yang tidak lain adalah imam madzhab yang empat - artinya bahwa dalam mengambil dan menggunakan produk fiqh (hukum Islam) dari ulama mujtahidin harus dikaji, diteliti dan dpertimbangkan terlebih dahulu sebelum dijadikan pedoman dan landasan bagi Nahdhatul Ulama.

Oleh karena itu, untuk meneliti dan mengkaji suatu produk fiqh (hukum Islam) dalam NU ada suatu forum pengkajian produk-produk hukum fiqh yang biasa disebut "Bahsul Masail ad-Diniyah (pembahasan masalah-masalah keagamaan)" (Amin, 1996). Jadi dalam forum ini berbagai masalah keagamaan akan digodok dan diputuskan hukumnya, Bunga yang selanjutnya keputusan tesebut akan menjadi pegangan bagi Jam'iyah Bank Nahdlatul Ulama.

Faham Nahdlatul Ulama dalam bidang tasawuf. Tasawuf sebenarnya merupakan dari ibadah yang sulit dipisahkan dan merupakan hal yang penting, terutama yang berkaitan dengan makna hakiki dari suatu ibadah. Jika fiqh merupakan bagian lahir dari suatu ibadah yang segala ketentuan pelaksanaannya sudah ditetapkan dalam agama, untuk 
mendalami dan memahami bagian dari ibadah, maka jalan yang dapat ditempuh adalah melalui tasawuf itu sendiri.

Di antara berbagai macam aliran tasawuf yang tumbuh dan berkembang, NU mengikuti aliran tasawuf yang dipelopori oleh Imam Junaid al-Bagdadi dan Imam al-Gazali. Imam Junaid al-Bagdadi adalah salah seorang sufi terkenal yang wafat pada tahun $910 \mathrm{M}$ di Irak, sedangkan Imam al-Gazali adalah seorang ulama besar yang berasal dari Persia.

Untuk kepentingan ini, yaitu membentuk sikap mental dan kesadaran batin yang benar dalam beribadah bagi warga Nahdlatul Ulama, maka pada tahun 1957 para tokoh NU membentuk suatu badan "Jam'iyah at-Tariqah al-Mu'tabarah" badan ini merupakan wadah bagi warga NU dalam mengikuti ajaran tasawuf tersebut. Dalam perkembangannya pada tahun 1979 saat muktamar NU di Semarang badan tersebut diganti namanya "Jam'iyah at-Tariqah al-Mu'tabarah an-Nadiyyah" (Amin, 1996). Dengan melihat nama badan tersebut di mana di dalamnya ada kata nadhiyyin ini menunjukkan identitasnya sebagai badan yang berada dalam linkungan Nahdhatul Ulama.

Selanjutnya, sejalan dengan derap langkah pembangunan yang sedang dilakukan, maka Nahdlatul Ulama sebagai bagian yang tidak terpisahkan dari masyarakat dan bangsa harus mempunyai sikap dan pendirian dalam dan turut berpartisipasi dalam pembangunan tersebut. Sikap dan pendirian Nahdlatul Ulama ini selanjutnya menjadi pedoman dan acuan warga NU dalam kehidupan beragama, bermasyarakat dan bernegara. Sikap NU dalam bidang kemasyarakatan diilhami dan didasari oleh sikap dan faham keagamaan yang telah dianut. Sikap kemasyarakatan NU bercirikan pada sifat: tawasut dan i'tidal, tasamuh, tawazun dan amar ma'ruf nahi munkar (Amin, 1996). Sikap ini harus dimiliki baik oleh aktifis Nahdlatul Ulama maupun segenap warga dalam berorganisasi dan bermasyarakat:

1. Sikap Tawasut dan I'tidal.

Tawasut artinya tengah, sedangkan I'tidal artinya tegak. Sikap tawasuth dan i'tidal maksudnya adalah sikap tengah yang berintikan kepada prinsip hidup yang menjunjung tinggi keharusan berlaku adil dan lurus ditengah-tengah kehidupan bersama (Shodik, 2000). Dengan sikap dasar ini, maka NU akan selalu menjadi kelompok panutan yang bersikap dan bertindak lurus dan selalu bersikap membangun serta menghindari segala bentuk pendekatan yang bersifat tatarruf (ekstrim).

2. Sikap Tasamuh.

Maksudnya adalah Nahdlatul Ulama bersikap toleran terhadap perbedaan pandangan, baik dalam masalah keagamaan teruma hal-hal yang bersifat furu' atau yang menjadi masalah khilafiyah maupun dalam masalah yang berhubungan dengan kemasyarakatan dan kebudayaan.

3. Sikap Tawazun.

Yaitu sikap seimbang dalam berkhidmad. Menyesuaikan berkhidmad kepada Allah SWT, khidmat sesama manusia serta kepada lingkungan sekitarnya. Menserasikan kepentingan masa lalu, masa kini dan masa yang akan datang.

4. Amar Ma'ruf Nahi Munkar. 
Segenap warga Nahdlatul Ulama diharapkan mempunyai kepekaan untuk mendorong berbuat baik dan bermanfaat bagi kehidupan bermasyarakat, serta mencegah semua hal yang dapat menjerumuskan dan merendahakan nilai-nilai kehidupan manusia.

Dengan adanya beberapa aspek tersebut di atas, diharapkan agar kehidupan umat Islam pada umumnya dan warga Nahdlatul Ulama pada khususnya, akan dapat terpelihara secara baik dan terjalin secara harmonis baik dalam lingkungan organisasi maupun dalam segenap elemen masyarakat yang ada. Demikian pula perilaku warga Nahdlatul Ulama agar senantiasa terbentuk atas dasar faham keagamaan dan sikap kemasyarakatan, sebagai sarana untuk mencapai cita-cita dan tujuan yang baik bagi agama maupun masyarakat.

- Pandangannya tentang Bunga Bank.

Persoalan bank dan bunganya dalam pandangan Nahdlatul Ulama (NU) telah menjadi persoalan yang signifikan, sehingga perlu mendapat perhatian yang cukup besar dari para ulama NU. Kaitannya dengan masalah bunga bank, NU melalui forum kajian Bahsul Masailnya telah mengaharamkannya, hal ini dikarenakan bunga bank disamakan dengan gadai yang digunakan pada zaman jahiliyah, jika pemilik barang gadai tidak bisa membayar uang pada waktunya, maka barang gadaiannya lepas dari pemiliknya dan menjadi milik penggadai dan hal ini telah ditetapkan hukumnya dalam Mu'tamar II tahun 1927 di Surabaya.

Dalam masalah bunga bank ini terdapat tiga pendapat dari para ahli hukum (ulama) (Hamid, t.t):

a. Haram : Karena termasuk barang yang dipungut manfaatnya (rente).

b. Halal : Sebab tidak ada syarat pada waktu akad, sebab menurut para ahli hukum terkenal, bahwa adat yang berlaku itu tidak termasuk menjadi syarat.

c. Syubhat : (tidak tentu halal-haramnya)

Sedangkan mu'tamar memutuskan, bahwa yang lebih hati-hati adalah pendapat mu'tamirin yang pertama-yakni mengaharamkan adanya bunga dalam dunia perbankan. Sikap NU ini didasari dengan mengambil hujjah dari kitab mu'tabar yaitu :

$$
\text { (ad Dimyati, t.t) }
$$

Adapun hukum menitipkan uang di bank, demi keamanan saja, NU menyatakan makruh kalau meyakinkan bahwa uangnya tersebut akan digunakan untuk kegiatan yang melanggar norma-norma agama (Mukhdor, 1992).

Dalam keputusan lain juga telah ditetapkan:

Mengigat bahwa dalam bank, pihak debitur memiliki dan

Bunga

Bank bertanggungjawab penuh atas uang yang dipinjamkan dan bunganya ditentukan atas dasar untung rugi atau besar kecilnya keuntungan dari hasil usahanya, maka transaksi bank tersebut termasuk dalam akad qard dan dengan sendirinya bunga bank termasuk riba qard. Dilihat dari sudut ini bahwa besar kecilnya bunga tergantung pada lama atau sebentarnya tempo pengambilan bunga bank cenderung masuk dalam riba nasi'ah yang berlipat ganda (TIM, 1993). 
Meskipun telah diambil kesepakatan tentang hukum bunga bank, tampaknya para muktamirin masih berbeda pendapat, terutama dalam Munas 'Alim Ulama di Bandar Lampung, 21-25 Januari 1992, khususnya mengenai hukum bunga bank konvensional. Di antaranya sebagai berikut:

a. Ada pendapat yang mempersamakan antara bunga bank dengan riba secara mutlak, sehingga hukumnya adalah haram.

b. Ada pendapat yang tidak mempersamakan bunga bank dengan riba, sehingga hukumnya adalah boleh.

c. Ada pendapat yang mengatakan bunga bank hukumya syubhat (tidak identik dengan riba).

Untuk menyelesaikan masalah tersebut, NU memberikan solusi: Mengingat warga NU merupakan potensi yang terbesar dalam pembangunan nasional dan dalam kehidupan sosial ekonominya, diperlukan adanya suatu lembaga keuangan sebagai peminjam dan pembina yang memenuhi syarat sesuai dengan keyakian keyakian warga NU, maka dipandang perlu untuk mencari jalan keluar menentukan sistem perbankan yang sesuai dengan hukum Islam, yakni bank tanpa suku bunga dengan langkah-langkah sebagai berikut:

a. Sebelum tercapainya cita-cita di atas, hendaknya sistem perbankan yang dijalankan sekarang ini harus segera diperbaiki

b. Perlu diataur dalam penghimpunan dana masyarakat dengan prinsip:

1) Wadi'ah (simpanan) bersyarat atau dhamanah, yang digunakan untuk menerima giro (current account) dan tabungan (seving account) serta pinjaman dari lembaga keuangan lain yang menganut sistem yang sama-Dalam hal ini yang menerima simpanan dana (bank) bertanggungjawab atas pengembalian dana tersebut sesuai dengan akad.

2) Mudarabah dalam prinsip ini pemilik dana bersepakat dengan bank untuk melakukan usaha bersama dengan membagi keuntungan yang diperoleh dengan suatu rasio yang telah disepakati terlebih dahulu.

Dalam prakteknya, bentuk ini disebut investment account (deposito berjangka), mislanya 3 bulan, 6 bulan dan sebagainya, yang pada garis besarnya dapat dinyatakan dalam:

1) Genaral Investment (GIA). Peraturan perbankan mewajibkan pengembalian dana nasabah secara utuh pada saat jatuhnya jangka waktu deposito, atau dapat ditarik seluruhnya jika dikehendaki oleh nasabah karena ia sebagai titipan (wadi'ah/amanat).

2) Special Investment (SIA). Dana digunakan untuk membiayai proyek atau jenis perdagangan tertentu sesuai dengan kesepakatan kedua belah pihak. Sumber dana Bank Islam dapat juga dalam bentuk infaq, zakat, sedekah, hibah dan lain-lainnya. Special Investment ini meliputi:

a. Penanaman dana dan kegiatan usaha. Dalam penanaman dana atau kegiatan usaha lainnya, bank Islam pada dasarnya bergerak dalam tiga bidang yaitu:

- Pembiayaan proyek

- Pembiayaan perdagangan perkongsian

- Pemberian jasa atas dasar upaya melalui usaha patungan, profit sharing dan sebagainya.

Abdul

Salam

b. Untuk proyek financing sistem yang dapat digunakan, atara lain: 
(1) Mudarabah muqaradah

(2) Musyarakah

(3) Murabahah

(4) Pemberian kredit dengan service change (bukan bunga)

(5) Ijarah

(6) Bai' ad-Dain, termasuk di dalamnya Bai' as-Salam

(7) Al-Qard al-Hasan (pinjaman kredit tanpa bunga, dan tanpa service change)

(8) Bai' al-'Ajil.

c. Untuk aqriten participation, bank dapat membuka LC (letter of credit) dan pengeluaran surat pinjaman. Untuk ini dapat ditempuh kegiatan tersebut dengan dasar:

(1) Wakalah

(2) Musyarakah

(3) Murabahah

(4) Ijarah

(5) Sewa-beli

(6) Bai' as-Salam

(7) Bai' al-Ajil

(8) Kafalah (garansi bank)

(9) Working capital financing (pembiayaan modal kerja) melalui purshase order dengan menggunak prinsip murabahah

d. Untuk jasa-jasa perbankan (banking service) lainnya, seperti pengiriman dan transfer uang, jual beli valuta asing dan penukarannya dan lainlain, tetap dapat dilakukan dengan menggunakan prinsip tanpa bunga (SekJen NU, 1992).

Selanjutnya berkaitan dengan bank-bank yang ada sekarang (bank yang didirikan pemerintah). Nahdlatul Ulama tetap memperbolehkan beroperasinya bank-bank dan bahkan pemerintah dapat mendirikan bankbank yang baru, karena kebutuhan yang kuat (hajat rajihah). Dalam hal ini NU menetapkan:

Indonesia sebagai negara yang melindungi tegaknya semua ajaran yang dianut oleh mayoritas penduduknya berada dalam posisi yang serba sulit. Di satu pihak negara dihadapkan pada sistem ekonomi modern yang tidak bisa lepas dari perbankan, di lain pihak negara didhadapkan pada ajaran agama yang mengharamkan adanya bunga. Dengan adanya kebutuhan yang mendesak dan tidak dapat dihindari itu, sementara bank Islam belum bisa memenuhi kebutuhan, maka sambil melakukan perbaikan secara bertahap, negara diperbolehkan untuk meneruskan operasinya bank milik pemerintah dan mendirikan bank-bank negara yang baru, disesuaikan dengan kadar kebutuhan (TIM Penyusun, 1993).

Bunga

Bank

Tampaknya pernyataan NU di atas masih terdapat sedikit kerancuan. Satu sisi NU mengharamkan bunga bank, di sisi lain NU memperbolehkan terbentuknya bank-bank pemerintah walaupun dengan keadaan darurat (emergency). Sehubungan dengan keadaan tersebut, NU membagi tiga katagori bagi umat Islam kaitannya dengan bank. Pertama, orang Islam yang dalam hidupnya tidak dapat terlepas dari bank seperti para pengusaha, para kontraktor dan lain sebagainya, dengan alasan darurat, maka boleh bermuamalah dengan bank. Kedua, orang Islam yang 
tidak terikat pada bank tetapi sangat butuh pada bank, maka hukumnya boleh berhubungan dengan bank tetapi disesuaikan dengan kadar kebutuhannya. Ketiga, bagi orang Islam yang tidak membutuhkan bank hukumnya haram untuk berhubungan dengan bank (TIM, 1993).

\section{b) Muhammadiyah dan Pandangannya Tentang Bunga Bank.}

\section{- Pokok-pokok Pikiran.}

Muhammadiyah merupakan salah satu orgnisasi Islam pembaharu di Indonesia. Muhammadiyah yang dibangun oleh K.H. Ahmad Dahlan sesungguhnya merupakan salah satu mata rantai yang panjang dari gerakan pembaharuan Islam yang dimulai sejak tokoh pertamanya, yaitu Ibnu Taimiyah, Ibnu Qayyim al-Jauziyah, Muhammad bin Abdul Wahab, Sayyid Jamaludin al-Afgani, Muhammad Abduh, Rasyid Rida, dan sebagainya. Pengaruh gerakan pembaharuan tersebut terutama berasal dari Muhammad Abduh melalui tafsirnya, al-Manar, suntingan dari Rasyid Rida serta majalah al-Urwatu al-Wusqa (WWW.Muhammadiyah.online.or.id).

Muhammadiyah sebagai persyarikatan yang merupakan gerakan Islam. Maksud gerakannya adalah melakukan dakwah Islam amar ma'ruf nahi munkar yang ditujukan dalam dua bidang perseorangan dan masyarakat. Dakwah dan amar ma'ruf nahi munkar dalam bidang yang pertama terbagi mrenjadi dua golongan, kepada yang Islam bersifat pembaharuan (tajdid) yaitu mengembalikan kepada ajaran-ajaran agama Islam yang asli dan murni dengan jalan menghilangkan bid'ah, khurafat, dan lain sebagainya. Yang kedua kepada yang belum Islam-bersifat seruan dan ajakan untuk mengikuti atau memeluk ajaran agama Islam. Adapun Dakwah dan amar ma' ruf nahi munkar dalam bidang yang kedua adalah kepada masyarakat, bersifat perbaikan dan bimbingan serta peringatan. Kesemuanya itu dilakukan bersama dengan bermusyawarah atas dasar taqwa dan mengharap keridhaan Allah semata-mata (Pasha dan Darban, 2000). Dengan melaksanakan dakwah amar ma'ruf nahi munkar dengan cara masing-masing yang sesuai, Muhammadiyah menggerakkan masyarakat menuju tujuaannya adalah; terwujudnya masyarakat yang Islam yang sebenar-benarnya.

Dalam perjuangan melaksanakan usaha menunju tujuan terwujudnya masyarakat Islam yang sebenar-benarnya di mana kesejahteraan, kebaikan dan kebahagiaan luas merata serta menuju tujuan terwujudnya masyarakat utma, adil dan makmur yang diridhai Allah SWT. Maka Muhammadiyah mendasarkan segala gerak dan amal usahanya atas prinsip-primsip yang tersimpul dalam Muqadimah Anggaran Dasar Muhammadiyah, yaitu (Pasha dan Darban, 2000):

a. Hidup manusia harus berdasarakan tauhid, ibadah dan taat kepada Allah SWT.

Dalam melaksanakan segala gerak dan kegiatannya maka tauhid dan tawakkal kepada Allah SWT harus senantiasa menjadikan landasan dasar utamanya, dengan maksud semata-semata untuk beribadah serta mentaati semua perintah dan larangan-Nya. Dasar seperti inilah yang harus menjadi ciri milik pribadi setiap warga Muhammadiyah sehingga dapat menjadi contoh teladan dalam bangunan dan perbaikan negara dan masyarakat. 
b. Hidup Manusia bermasyarakat.

Muhammadiyah adalah salah satu faktor yang kuat dalam perkembangan masyarakat serta warga Muhammadiyah merupakan anggota masyarakat yang tidak diam, akan tetepi bergerak maju, aktif dinamais dalam membangun. Oleh karena itu, gerakan Muhammadiyah harus aktif dan menonjol di tengah-tengah masyarakat untuk memimpin atau paling tidak menjadi sosok penerang yang cemerlang dalam kehidupan bermasyarakat.

c. Menegakkan ajaran Islam dengan keyakinan bahwa ajaran Islam adalah asatu-satunya landasan kepribadian dan ketertiban bersama untuk kebahagian dunia dan akhirat.

Muhammadiyah berkeyakinan bahwa tidak ada dasar landasan yang dapat membahagiakan manusia di dunia ini kecuali dengan dasar alQur'an dan as-Sunnah yang akan membawa kebahagian manusia yang hakiki di akhirat kelak. Oleh karena itu, apa pun ajaran Islam yang terkandung dalam al-Qur'an dan as-Sunnah wajib dan mutlak dipatuhi oleh setiap warga Muhammadiyah. Segala kebijaksanaan pimpinan serta taktik daa srrategi perjuangan harus dinilai dan sesuai dengan prinsipprinsip ajaran Islam.

d. Menegakkan dan menjunjung tinggi agama Islam dalam masyarakat adalah wajib, sebagai ibadah kepda Allah dan berbuat ihsan dan islah kepada kemanusiaan.

Setelah Muhammadiyah dapat berdiri tegak dan berjalan di atas landasan seperti di atas, barulah kuat untuk menegakkan dan menjunjung tinggi ajaran Islam serta mampu mengatasi berbagai rintangan, hambatan, tantangan dan segala halangan yang akan terjadi.

e. Ittiba' kepada langkah perjuangan Nabi Muhammad SAW.

Ittiba' atau mengikuti jejak langkah perjuangan Rasulullah SAW. adalah wajib menjadi syarat yang tidak boleh tidak harus dan wajib dilakukan oleh setiap muslim, dan sesungguhnya dalam rangka menggerakkan Umat Islam ke arah ittiba' itulah hakikatnya Muahammadiyah didirikan

Umat Islam wajib mencontoh sikap keteguhan Rasulullah dalam menghadapi penderitaan dan rintangan, kesabaran dalam duka dan derita serta kesyukurannya dalam menerima nikmat-nikmat Allah SWT-di mana umat Islam harus senantiasa berusaha memiliki sifat-sifat yang dicontohkan oleh Rasulullah SAW.

f. Melancarkan amal usaha dan perjuangannya dengan ketertiban organisasi.

Muhammadiyah beramal dan berjuang dengan berorganisasi yang

Bunga

Bank

103 didasarkan atau musyawarah bersama. Menghimpun dan mendidik kader
pimpinan, mengaktifkan gerak anggota, menentukan peraturan-peraturan untuk mencapai hasil yang jauh kebih besar dan lebih dapat menanggulangi berbagai rintangan dan halangan karena bergerak dengan menggunakan sebuah organissi.

\section{- Pandangannya tentang Bunga Bank}

Mu'tamar Majlis Tarjih Muhammadiyah setelah mempelajari (PP.Muhammadiyah, t.t): 
a. Uraian tentang masalah bunga bank dalam segala seginya yang disampaikan oleh Nandang Komar, Direktur Bank Negara Indonesia Unit 1 Cabang Surabaya.

b. Pembahasan dari para Mu'tamirin

Dengan bertawakkal kepada Allah SWT.

\section{Mengingat:}

1) Bahwa nash-nash al-Qur'an dan as-Sunnah dengan jelas mengharamkan riba.

2) Bahwa fungsi bank dalam perekonomian modern sekarang ini bukan hanya menjadi sumber penghasilan bagi bank, melainkan juga berfungsi sebagai alat politik perekonomian Negara untuk kesejahteraan umat (stabilisasi ekonomi).

3) Bahwa adanya undang-undang yang mengatur besar kecilnya bunga adalah untuk mencegah kemungkinan terjadinya penghisapan pihak yang kuat terhadap pihak yang lemah di samping untuk melindungi berlangsungnya kehidupan bank itu sendiri.

4) Bahwa hingga saat ini belum ada konsepsi sistem perekonomian yang disusun dan dilaksanakan dengan kaidah Islam.

\section{Menimbang:}

1) Bahwa nas-nas al-Qur'an dan as-Sunnah tentang haramnya riba mengesankan adanya 'illat terjadinya penghisapan oleh pihak yang kuat terhadap yang lemah.

2) Bahwa perbankan adalah suatu sistem lembaga perekonomian yang belum pernah dialami umat Islam pada masa Rasulullah SAW.

3) Bahwa hasil keuntungan Bank-bank milik Negara pada akhirnya akan kembali untuk kemaslahatan umat.

4) Bahwa termasuk atau tidaknya bunga bank ke dalam pengertian riba Syar'i dirasa belum mencapai bentuk yang meyakinkan

\section{Memutuskan:} Sunnah.

1) Riba hukumnya haram, dengan nas sarih al-Qur'an dan as-

2) Bank dengan sistem riba hukumnya haram dan bank tanpa riba hukumnya halal.

3) Bunga bank yang diberikan oleh Bank-bank milik Negara kepada para nasabahnya atau sebaliknya yang selama ini berlaku, termasuk perkara Musytabihat (PP. Muhammadiyah, t.t).

4) Menyarankan kepada PP. Muhammadiyah untuk mengusahakan terwujudnya konsepsi sistem perekonomian khususnya lembaga perbankan yang sesuai dengan kaidah Islam.

\section{E. Kesimpulan.}

1. Bahwa dalam merespon tentang masalah bunga bank, NU telah melakukan ijtihad (jama'i) ketika menghadapai persoalan fiqh kontemporer, khususnya persoalan bunga bank, akan tetapi juga tidak meninggalkan cara-cara lama. Yaitu bermazhab secara qauli, dengan hanya mengambil pendapat ulama (Syafi'iyah) secara sporadis dan apa adanya. Ijtihad bagi NU hanya dilakukan jika "benar-benar" persoalan hukum Islam yang dihadapi tidak ditemukan dalam kitabkitab mu'tabar. Dan paling jauh menerapkan metode ijtihad yang telah 
dibangun oleh ulama terdahulu, karena sebagai cermin sikap tawaddu' NU kepada mereka. Lebih lanjut, dalam hal ini (masalah bunga bank) NU memandang bahwa hukum tentang bunga bank adalah sebagaimana yang telah diputuskan dalam Sidang Lajnah Bahsul Masa'il NU di Malang, Jawa Timur tahun 1937, yang memutuskan: Pertama, haram, karena termasuk utang yang dipungut rente. Kedua, halal, karena tidak ada syarat pada waktu aqad, sementara adat yang berlaku tidak dapat begitu saja dijadikan syarat. Ketiga, syubhat, sebab para ahli berselisih paham tentangnya. Meski begitu, Lajnah memutuskan, pilihan yang lebih berhati-hati adalah bunga bank haram.

2. Sementara Muhammadiyah menggunakan qiyas sebagai metode ijtihad dalam merespon bunga bank. Bagi Muhammadiyah 'illat diharamkannya riba adalah adanya pengisapan atau penganiayaan (az-Zulm) terhadap peminjaman dana. Konsekuensinya, kalau 'illat itu ada pada bunga bank, maka bunga bank sama dengan riba dan hukumnya riba. Sebaliknya kalau 'illat itu tidak ada pada bunga bank, maka bunga bank bukan riba, kerana itu tidak haram. Bagi Muhammadiyah 'illat diharamkannya riba disinyalir juga ada pada bunga bank, sehingga bunga bank disamakan dengan riba dan hukumnya adalah haram. Namun keputusan tersebut hanya berlaku untuk bank milik swasta. Adapun bunga bank yang diberikan oleh bank milik negara pada para nasabahnya atau sebaliknya, termasuk perkara musytabihat, tidak haram dan tidak pula halal secara mutlak. Pendapat Muhammadiyah mengacu pada hasil mu'tamar Majlis Tarjih Muhammadiyah di Sidoarjo Jawa Timur, tahun 1968 yang memutuskan: Pertama, riba hukumnya haram dengan nas sarih alQur'an dan as-Sunnah. Kedua, Bank dengan sistem riba hukumnya haram dan bank tanpa riba hukumnya halal. Ketiga, Bunga yang diberikan oleh bank milik negara kepada para nasabahnya atau sebaliknya, termasuk perkara musytabihat (yang meragukan).. Keempat, Menyarankan pada PP Muhammadiyah untuk mengusahakan terwujudnya konsepsi sistem perekonomian, khususnya lembaga perbankan, yang sesuai dengan kaidah Islam.

3. Baik NU Maupun Muhammadiyah sama-sama sependapat bahwa riba hukumnya adalah haram hal ini berdasarkan pada nas sarih alQur'an dan al-Hadis yang dengan jelas-jelas telah mengharamkan adanya praktek riba. Meskipun dalam melihat aplikasi hukum Islam tentang riba sama-sama mengharamkanya, tetapi NU dan Muhammadiyah memiliki cara pandang atau berfikir yang berbeda. Bagi NU bahwa hukum bunga bank adalah haram baik itu bank milik

Bunga

Bank

105 swasta maupun bank milik negara. Lebih lanjut, NU mengungkapkan bahwa bunga yang diambil oleh penabung di bank adalah riba yang diharamkan. Artinya, apa yang diambil seseorang tanpa melalui usaha perdagangan dan tanpa bersusah payah sebagai tambahan pokok hartanya, maka yang demikian itu termasuk riba. NU kemudian menguatkan pendapatnya, bahwa pengambilan bunga bank oleh nasabah yang menyimpan uangnya di bank adalah haram. Dalam hal ini NU lebih tegas dalam menetapkan keharaman bunga bank-yaitu 
apabila pihak bank menggunakannya untuk perbuatan yang telah dilarang agama. Sedangkan bagi Muhammadiyah agaknya masih ragu terhadap ada atau tidak adanya 'illat riba pada bank milik negara, hal ini terlihat dengan penetapan, bahwa hukum bunga bank milik negara adalah musytabihat. Alasan mengatakan musytabihat, adalah karena ada dua kecenderungan yaitu halal atau haram, di samping juga karena dalam bank itu tidak dibedakan antara orang yang meminjam uang untuk konsumsi dan meminjam untuk diproduksikan. Maka hal ini harus dihindari, kecuali dalam keadaan darurat (terpaksa). Tampaknya keputusan Muhammadiyah ini sejalan dengan pendapat yang mengatakan bahwa bunga bank boleh karena darurat, seperti pendapat Mustafa az-Zarqani, yang mengatakan bahwa bank merupakan kenyataan yang tidak dapat dihindarkan. Karenanya umat Islam boleh bermu'amalah dengan bank atas pertimbangan darurat. Lebih lanjut, Muhammadiyah menyatakan, bahwa riba yang diharamkan oleh agama adalah sifat pembungaan yang selalu disertai unsur penyalahgunaan kesempatan dan penindasan. Sedang yang berlaku dewasa ini sama sekali tidak menimbulkan rasa penindasan atau kekecewaan oleh siapapun yang berkepentingan.

Abdul

Salam 


\section{DAFTAR PUSTAKA}

Abbas, Anwar, 2003, Hukum Bunga Bank Konvensional, makalah disampaikan pada diskusi Majlis Tarjih tentang Bunga Bank, diselenggarakan oleh Pengurus Pusat Muhammadiyah, Jakarta

ad-Dimyati, Sayyid Bakr, t.t., Ianah at-Talibin Semarang: Toha Putra t.t.

Amin, Masyhur, M., 1996, NU dan Ijtihad Politik Kenegaraannya, cet, I Yogyakarta: Al-Amin Press.

as-Sabuni, Ali, 1972, Rawai 'al-Bayan fi at-Tafsir Ayati al-Ahkam, Dar alQur'an

Chotib, A., 1962, Bank dalam Islam, Jakarta: Bulan Bintang

Chuzaimah T. Yanggo dkk (ed.), 1995, Problematika Hukum Islam Kontemporer, cet. I Jakarta: Pustaka Firdaus, 1995

Djamil, Faturrahman, 1995, Metode Ijtihad Majlis Tarjih Muhammadiyah, cet. I Jakarta: Logos Publishing House

Fahruddin, Fuad M., 1985, Riba dalam Bank: Koperasi, Perseroan dan Asuransi, Bandung: al-Ma'arif

Hadi, Abu Sura'i Abdul, 1993, Bunga Bank dalam Islam, alih bahasa M. Tholib, Surabaya: al-Ikhlas

Hadiwigeno, Soetatwo, 1984, Lembaga-lembaga Keuangan dan Bank, Yogyakarta: UGM Press

Hamid, Abu Hamdan Abdu al-Jalil, t.t., Ahkam al-Fuqaha' fi alMuqarrarat Mu'tamarat Nahdatu al-Ulama', Semarang: Toha Putra

Hamid, Abu Hamdan Abdu al-Jalil, t.t., Ahkam al-Fuqaha' fi al-Muqarrarat Mu'tamarat Nahdatu al-Ulama', Semarang: Toha Putra, t.t..

Hasan, A., 1983, Soal-Jawab: Tentang Berbagai Masalah Agama, Bandung: Diponegoro

Hasan, Ali, M., 1996, Masail Fiqhiyyah: Zakat, Pajak, Asuransi dan Lembaga Keuangan, Jakarta: Raja Grafindo Husada

Manan, Abdul, M., 1997, Teori dan Praktek Ekonomi Islam,alih bahasa Nastangin, Yogyakarta: Dana Bakti Wakaf

Maridjan, Kacung, 1992, Quo Vadis NU Setelah Kembali ke Khittah 1926 Jakarta: Erlangga

Muhammad, 2000, Lembaga-lembaga Keuangan Umat Kontemporer, cet. I ( Yogyakarta

Mukhdlor, Zuhdi, 1992, NU dan Beberapa Soal Keagamaan, cet I Yogyakarta: Multi Karya Grafika

Muslehuddin, Muhammad, 1994, Sistem Perbankan dalam Islam, Jakarta: PT. Rhineka Cipta

Bunga

Bank

107

Najetullah, Muhammad, 1984, Bank Islam, alih bahasa Asep Hikmat Suhendi, Bandung: Penerbit Pustaka

Nasution, Khoiruddin, 1996, Riba dan Poligami: Sebuah Studi atas Pemikiran Muhammad Abduh, cet, I Yogyakarta: Pustaka Pelajar

Pasha, Kamal, Mustafa dan Ahmad Adaby Darban, 2000, Muhammadiyah sebagai Gerakan Islam: Dalam Perspektif Historis dan Ideologis, cet. I Yogyakarta: LPPI

Pimpinan Pusat Muhammadiyah, t.t., Himpunan Putusan Majlis Tarjih Muhammadiyah, Yogyakarta: Persatuan 
Pimpinan Pusat Muhammadiyah, t.t., Himpunan Putusan Majelis Tarjih Muhammadiyah, Yogyakarta: Persatuan

Rahman, Afzalur, 1996, Doktrin Ekonomi Islam, alih bahasa Soeroyo dan Nastangin, Yogayakarta: Dana Bakti Wakaf

Rasjid, Sulaiman, 1997, Fiqh Islam: Hukum Fiqh Lengkap, Bandung: Sinar Baru Algasindo

Saeed, Abdullah, 2003, Bank Islam dan Bunga, alih bahasa Muhammad Ufuqul Mubin. cet I Yogyakarta: Pustaka Pelajar

Sekretariat Jenderal Pengurus Besar Nahdlatul Ulama, 1992, “Bank Dalam Islam", materi pelengkap disajikan pada Munas 'Alim Ulama NU tentang hukum bunga bank, diselenggarakan oleh Pengurus Besar Nahdlatul Ulama, Bandar Lampung

Sekretariat Jenderal Pengurus Besar Nahdlatul Ulama, 1999, Hasil-hasil Muktamar XXX Nahdhatul Ulama Jakarta: Sek. Jen. PBNU

Shodik, Mohamad, 2000, Gejolak Santri Kota: Aktivitas Muda NU Merambah Jalan Lain, cet. I ,Yogyakarta: Tiara Wacana

Sugiri, 1998, Studi Perbandingan Pelaksanaan Tata Cara Penetapan Hukum antara Majlis Tarjih Muhammadiyah dan Syuriah NU, skripsi tidak diterbitkan, Yogyakarta: IAIN Sunan Kalijaga

Sukarja, Ahmad, 1995, Riba, Bunga Bank, dan Kredit Perumahan, Pustaka Firdaus

Tim Penyusun, 1993, Keputusaan Munas Alim Ulama dan Konbes Nahdlatul Ulama di Bandar Lampung 1992, Lajnah wa Ta'lif wa Nasyr,(Semarang: Sumber Barakah

www.muhammadiyah.online.or.id, Tokoh Pendirinya, hlm, 1-2.

www.sabili.or.id

Zaini, Wahid, A., 1994, Dunia Pemikiran Kaum Santri Yogayakarta: LKPSM

Zaini, Wahid, A., 1994, Dunia Pemikiran Kaum Santri, Yogayakarta: LKPSM

Zuhdi, Masjfuk, 1998, Masail Fiqhiyah, cet VIII Jakarta: Surya Grafindo

Zuhri, M., 1996, Riba dalam Al-Qur'an dan Masalah Perbankan: Sebuah Tilikan Antisipatif, cet.I Jakarta: Raja Grafindo Persada

Zuhri, Muhammad, 1996, Riba dalam al-Qur'an dan Masalah Perbankan: Sebuah Tilikan Antisipatif, cet. I Jakarta: Raja Grafindo

Abdul

Salam 